\title{
Andreas Winkler* Stellar Scientists: The Egyptian Temple Astrologers
}

https://doi.org/10.1515/janeh-2020-0017

Published online June 29, 2021

Abstract: The paper aims to collect and discuss evidence for astrologers in Egyptian temples during the Graeco-Roman period from several kinds of data, including astrological and astronomical texts, inscriptions, and documentary sources. Material evidence is also considered. It attempts to answer questions of who could act as an astrologer and what knowledge was required to become one. In addition, the paper discusses the position of astrologers in the temple hierarchy and other areas of knowledge in which astrologers were involved.

Keywords: astrology, astronomy, astral knowledge, astrologers, astronomers, practitioners, priests, temples, Graeco-Roman Egypt

\section{Introduction}

Zodiacs appear as a new element in the decoration programmes of temples in the Graeco-Roman period. ${ }^{1}$ The first tangible evidence comes from the late Ptolemaic period, while most can be dated to the reign of the Caesars, ${ }^{2}$ a time when astrology came into vogue across the Empire. This was a theological innovation that had a deep impact on Egyptian society. It reached beyond the temples; tombs and coffins

1 E.g. Neugebauer and Parker 1969: 7 and 203-212. Numerous studies of these have been conducted, but this is not the place to provide references to specific items.

2 Quack 2018a: 81 re-dates the Esna zodiac to the second century AD, while it was previously assumed to be Ptolemaic. There are, however, a few monuments that date to the reign of Cleopatra VII and Caesarion. Baines 2020: 76, n. 84, puts forward the idea that the precise lifespan of individuals mentioned in some of the Ptolemaic autobiographies-once pinpointed down to the hour of birth-could indicate horoscopic or related practices. Yet, since similar practices appear in such texts from earlier times, he questions a direct connection. In the Hellenic world, the tomb of Antiochus I of Commagene poses another early example of monumentalising zodiacs or horoscopes (e.g. Neugebauer and van Hoesen 1959: 14-16; Gieseler Greenbaum 2020: 452).

*Corresponding author: Andreas Winkler, Freie Universität Berlin, Institut für Wissensgeschichte des Altertums, Arnimallee 10, 14195 Berlin, Germany; and Einstein Center Chronoi, Berlin, Germany, E-mail: andreas.winkler@fu-berlin.de 
could also be embellished with ornamentations involving the zodiac and related concepts. While the depictions in the sepulchral sphere often attempt to configure the planets and the zodiac signs to provide the date of birth of the interred person(s), the temple zodiacs tend to depict the planets in their exaltation or houses. ${ }^{3}$ That is, they represent the thema mundi, ${ }^{4}$ the arrangement of the celestial bodies at the beginning of the world, and thus express ideas central to astrology as it was practiced in Egypt. The thema mundi depicting the planets in their houses is in itself an Egyptian concept that can be linked to the rising of Sothis at the beginning of an Egyptian year. ${ }^{5}$

The connection between astrology and Egypt was already recognised in antiquity: the Egyptians were often credited with the discovery of astrology. The invention of the art was ascribed to the higher echelon of Egyptian society. The adjutants of royalty or the royals themselves were said to have revealed the arcane art in a glorious past. The famous sage Imhotep, son of Ptah, in the time of Pharaoh Djoser, is found among the names of the discoverers. ${ }^{6}$ In Greek sources, he is often referred to as Asclepius, and he can be accompanied by Hermes, ${ }^{7}$ who in the Egyptian world, alongside the god of wisdom Thoth, was known as Amunhotep, son of Hapu. Other individuals who passed this information down to later times include the sages Petosiris or Petesis and King Necho II, often called Nechepso(s). ${ }^{8}$ Such attributions placed the birth of astrology in the great centres of Egyptian learning, such as Heliopolis, Memphis, and Thebes. This image is common to both Egyptian language sources and Greek papyrological ones. ${ }^{9}$ The latter of course drew on the former. In the classical texts, other figures also make an appearance as Egyptian authors of astrological treatises, including Chaeremon and Melampus, who were regarded as hierogrammateis. ${ }^{10}$ In addition, individuals who possessed a

3 See e.g. Neugebauer and van Hoesen 1959: 7; Neugebauer and Parker 1969: 202-203; Leitz 2006: 286-287.

4 E.g. Quack 2016: 233; von Lieven 2020: 417.

5 Leitz 2006: 287-289; Quack 2018a: 92; Nagel 2019: 264. The exaltations, on the other hand, have a Babylonian background, being equivalent to the bit nișirti, "secret house" (Rochberg 1998: 47-50). See also Hoffmann 2014: 83-84. Pries 2011: 28-29 points out that such depiction in temples and tombs are associated with the Stundenwachen ritual. They would have been connected to the division of nocturnal hours. Needless to say, such a symbolic extension of the zodiac would have no practical value. Other instruments were used for the actual timekeeping (see $\mathrm{n} .97$ below).

6 Chauveau 1992: 102; Quack 2002a: 89-90; Ryholt 2009: 305-314; Winkler 2009: 373; Cauville 2010: 19 and 21; Quack 2016: 232-233.

7 See e.g. P.Louvre 2342bis from Upper Egypt (Neugebauer and van Hoesen 1959: 42-43).

8 Ryholt 2011: 61-72. See also Winkler 2016: 248, n. 14, with further references; Quack and Ryholt 2019: 172-174.

9 Heilen 2015: 539-562; Altmann-Wendling 2019: 239-242.

10 E.g. Lippold 1931: 392-405; van der Horst 1987. 
less prominent place in the intellectual history of Egypt could be ascribed authorship of astrological treatises. The prime example of this is found in P.Vindob.Dem. 6614, ${ }^{11}$ which is attributed to a priest of Amunrasonther in Thebes. ${ }^{12}$

It is clear that the art of astrology was highly revered; it had a place in the intellectual sphere much on the same level as medicine, magic, various other types of divinatory techniques, and several religious texts. Its place in Egyptian society was clearly tied to the temple. ${ }^{13}$ The priests were the keepers of knowledge and wisdom, the "scientists" of Egyptian society. The question is, therefore, who was practicing this illustrious art in the Egyptian temples? Was it practiced only by a select few, the higher strata of the manifold priesthoods, or was it pursued by priests from a wider range of sacerdotal ranks?

\section{What Were the Requirements?}

What did an ancient Egyptian astrologer have to know in order to cast someone's nativity? Of course, knowledge of reading and writing were prerequisites, as well as an awareness of the basics of astrology, for instance, the zodiac, but what beyond this? The answer depends on the type of astrology that the particular practitioner wanted to pursue.

The astrological manuals operated by the Egyptian temple astrologers displayed great variety. This material needs a far more detailed and penetrating analysis than can be offered here to do them justice, yet a brief survey can be offered. For natal astrology, the preserved Demotic handbooks of this kind suggest

11 The text was originally published by Reymond 1977: 143-157. It was not recognised as an astrological treatise in the ed.pr. The content of the text was, however, understood by Smith 1985: 111-114; Hughes 1986: 69.

12 Quack 2002a: 90-91. The name of the alleged author is unfortunately lost, but Quack suggests that there is a possibility that the named person was indeed a real person and not a figure of legends. His titles are preserved. Though he carried the title $w c b$-priest, he belonged to the higher sacerdotal ranks, being a hierogrammateus (sh $n$ pr- $n h$ h).

13 E.g. Cumont 1937: 113-131; Jones 1994: 40-47; Evans 2004: 25-27. The Greek evidence may suggest that there were practitioners of this art outside the temple sphere (e.g. Hübner 2020: 301-304). That astral knowledge diffused from the temples after having been practiced there is hardly surprising in view of the fact that other types of divinatory techniques also left the confines of the sacred precincts. It is possible that this can in part be connected with the demise of institutionalised religion in Egypt by the third or early fourth century AD (see e.g. Love 2016: 261-271; Smith 2017: 421-537). Across the Empire as a whole, the connection to a priesthood is perhaps less straightforward. It is commonly assumed that the majority of astrologers were freelancing practitioners (Rives 2011: 281-285). 
that there were two main types of techniques, based on which parameters were primarily considered for establishing a prediction. ${ }^{14}$ One type primarily correlated the position of the five planets (Saturn, Jupiter, Mars, Venus, and Mercury) and the two luminaries-the Sun and the Moon-with the zodiac signs. The positions were then transposed onto, for instance, the Dodecatropos, a division of the sky into 12 compartments, arranged counter-clockwise relative to the ascendant. ${ }^{15}$ These were believed to affect various aspects of the native's life depending on whether a planet was located there or not. The lots (see below) could also be relevant, as well as the terms (dny.t) for establishing a detailed and correct prognostication of an individual's life. ${ }^{16}$ These are portions of every zodiac sign assigned to each planet. When the celestial body occupied its own terms, it was thought of as extra influential. The terms were also important for establishing the extent of the native's lifetime.

The second type of manual also depends on the zodiac, but divides each one of the 12 signs, each of which occupies $30^{\circ}$ of the ecliptic, into three segments of $10^{\circ}$. Each such segment was associated with one of the 36 decans, i.e. three decans per zodiac sign. Usually, the positions of the Sun and the Moon were specified in relation to decans, less often also those of the planets. ${ }^{17}$

Most preserved texts making predictions about the well-being of the country base their forecast on the appearance of Sothis. ${ }^{18}$ These treatises consider the positions of the planets in the zodiac signs or the decans at the time of the star's rising, but weather phenomena and the colour of the star could likewise be taken into account. ${ }^{19}$ Similar predictions were also connected to solar and lunar eclipses and phenomena of the planet Mercury. ${ }^{20}$

The procedure that the astrologer needed to undertake in order to find the positions of the planets consisted of several steps. First, of course, he needed to

14 Winkler 2009: 364-366.

15 E.g. Bouché-Leclercq 1899: 257-275; Neugebauer and van Hoesen 1959: 7-8; von Lieven 1999: 100-101 and 123-124; Heilen 2015: 689-702.

16 See Winkler 2018: 304, n. 34. For the terms in general, see Bouché-Leclercq 1899: 206-215; Neugebauer and van Hoesen 1959: 12; Heilen 2010: 45-93; 2015: 718-731; Steele 2015: 187-215. For earlier discussion, specific to previously published Egyptian material, see Depuydt 1994: 1-9; Bohleke 1996: 11-46, esp. 34-46.

17 Chauveau 1992: 104. See also von Lieven 2000a: 26.

18 A published Demotic example is P.Cair. II 31222 from Tebtunis (Hughes 1951: 256-264). See Quack 2017b: 200-201 for an improved translation. Recently Stadler 2018: 395-411 published another Demotic example from Soknopaiou Nesos. The disaster year text of P.Carlsberg XI 22 is related to this genre according to its editor. Texts in Greek include P.Gen. III 123; P.Merton II 57; P. Oxy. XXXI 2554; LXV 4471-4472 (see also Jones 1998: 131-133 with further references).

19 Quack 2018a: 93.

20 See $n$. 86 below. 
know the date and the hour of the parturition (see below), and, ideally, also the geographical location, ${ }^{21}$ since the length of the hour varies depending on the geographical location. Based on this information he would be able to determine the positions of the celestial bodies with the help of various tools, and these positions could be written down. The result was a horoscope. With this information, finally, the astrologer could turn to his manual to look up the relevant entries before delivering the forecast to the client.

\subsection{Horoscopes and Other Tools}

Looking at the preserved horoscopes from Egypt, ${ }^{22}$ one can note variation in format in both the Greek and Egyptian materials. It is possible to speak of deluxe horoscopes, elaborate horoscopes, and basic horoscopes. ${ }^{23}$ The latter are by far the most common type. Though these can be configured in a variety of ways, ${ }^{24}$ they all provide essentially the same information. As a rule, they specify the location of the Sun and the Moon, and that of the five planets as whole zodiac signs. This is usually complemented by the position of the ascendant, i.e. the rising point of the ecliptic. The date and time of the birth tend to be recorded as well (e.g. O.Berlin 6152). ${ }^{25}$ What is referred to as an elaborate horoscope contains slightly more detail. The additional data is of both astronomical and astrological nature. The added astronomical information usually consists of the precise longitude of the planets in the zodiac signs. The astrological information is by and large contingent on the astronomical, and can include further information on the Dodecatropos, the terms, and the lots (e.g. O.Ashm.Dem. 633; P.Oxy. II 307). ${ }^{26}$ The deluxe horoscopes are far more advanced in terms of their underlying astronomical calculations. Here the positions are often specified down to minutes, and they may include references to decans and other astrological dignities (e.g. P.Lond. I 98 and 130). ${ }^{27}$ They are, so to

21 See Jones 2007: 309.

22 See Heilen 2015: 213-326; Winkler 2018: 298-308. A recent overview of the Demotic evidence is furnished by Ross 2020: 509-526. For the Greek and Latin examples, see Gieseler Greenbaum 2020: 443-471; Heilen 2020a: 428-446.

23 Jones 1999a: 249 makes a distinction between regular and deluxe horoscopes.

24 E.g. Neugebauer and van Hoesen 1959: 162-163; Ross 2006: 156.

25 Neugebauer and Parker 1968: 234-235.

26 Winkler 2018: 304, n. 34; Neugebauer and van Hoesen 1959: 19-20. The Demotic text is also discussed by Gieseler Greenbaum 2020: 452 and 467; Ross 2020: 514-515. Both only refer to the $e d$. pr. (Neugebauer and Parker 1968: 231-234).

27 Neugebauer and van Hoesen 1959: 21-38. See Winkler 2016: 263-267 for the first mentioned one (the so-called Old Coptic Horoscope). The latter is treated in great detail by Beck 2013: 397-406; Heilen 2020b: 255-256 and 258-266. 
speak, lavish versions of the elaborate horoscopes, though admittedly it is somewhat arbitrary where the line is to be drawn between each category.

How did the practitioner establish the positions found in a typical horoscope? It seems that this could be a rather straightforward affair if one had access to appropriate materials; all established positions were the result of "theory, modelling, and calculations". ${ }^{28}$ So what did the astrologer do? As mentioned above, the first piece of information that the diviner required was the date and time of birth of his client. The date of birth would be necessary for establishing the position of the planets and the two luminaries on a particular date, while the hour of birth was required to determine the ascendant. It was also significant for various other astrological implications: often a nocturnal birth meant a different future than a diurnal one (see below). This information was probably conveyed orally to the astrologer. There are, however, several examples where the dates were noted down as a kind of an astrologer's aide-mémoire. ${ }^{29}$

The ostracon OMM 423 from second century AD Narmouthis relates to such a procedure. The text is an "astrological admonition" written in a mixed script of Demotic and Greek. The relevant part of the text reads as follows: "Bring the great pinax and come with a pen and the great list of regnal year 3 of Petosiris as well as the

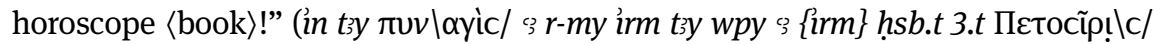
irm pзy $\left\langle\underline{d} m^{c}\right\rangle \dot{\omega} \rho \operatorname{soc} \backslash\langle\pi \kappa \tilde{\omega} v /) .^{30}$ The text reveals that an astrologer needed at least three tools to produce a horoscope in addition to a pen. The latter was mentioned, most probably, because the practitioner had to excerpt information from the two "books". Secondly, he could use a pinax. ${ }^{31}$ This device is a board that could be made of various materials, such as wood or ivory. It commonly depicts the heavens with, for instance, a zodiac. The position of the celestial bodies and other astrologically relevant points could be visualised with the help of various markers, for which gemstones were preferably used. The text may suggest that the astrologer used the pinax during his calculations, but it is also clear from other texts, e.g. O.Narm.Dem. II 82.1-7 (see below) that it was used when meeting the client. Another vivid example of how a pinax was used is put forward by an episode in the Alexander Romance

28 Jones 2007: 310.

29 A few such texts have been published in Demotic (e.g. Hoffmann 1995: 22-26; Menchetti 2009: 227-230; Ross 2009) and Greek (e.g. Bastianini and Gallazzi 1990: 5-7; Menchetti and Pintaudi 2007: 234-241).

30 Menchetti 2009: 231-232.

31 E.g. Nenna 2002: 355-376; Evans 2004: 4-14; Gieseler Greenbaum and Ross 2015: 109-129; Nawotka 2017: 52; Gieseler Greenbaum 2020: 457-458. See Gury 1996: 257; Hübner 2020: 314-315 for general overviews of the instruments and tools that could have been employed by an astrologer. It is unlikely that the equipment described would have been in the possession of every practitioner. 
when King Nectanebo casts the horoscope of Queen Olympias. ${ }^{32}$ This literary text does not mention any written tools that may have been used by Egyptian astrologers. The ostracon mentions two items that may be such tools, namely a "great list of regnal year 3 of Petosiris" and a "horoscope 〈book〉". In what follows, an attempt is made to answer the question of what information these texts may have contained.

\subsection{Astronomical Texts}

As already mentioned, one of the first steps that the astrologer needed to take was to determine the positions of the planets on the date provided to him. He could check it against the information found in so-called sign entry almanacs, of which there are several Egyptian examples including the so-called Stobart Tables and P.Berlin $8279 .^{33}$ These texts, which have been preserved in the two languages in use in Egypt during the relevant period, ${ }^{34}$ contain extensive lists of dates on which the five planets enter a new zodiac sign. They usually cover several years and the information is rather unprecise. This fact explains the rudimentary nature of most horoscopes, which only report the position of the planets in terms of a whole sign. With the help of sign-entry almanacs, it is a fairly straightforward affair to establish a regular, simple horoscope. For more precise calculations other tools could be used. For instance, the Roman-period P.Monts.Roca. inv. 314 included synodic phenomena in addition to sign entries, and P.Carlsberg 32 contains a table with daily positions of Mercury as a morning star. ${ }^{35}$ Other Demotic texts from the same period include O.Ashm.Dem. 483, which contains instructions for computing the first appearance of said planet as an evening star using a Babylonian model. On this ostracon the number of revolutions of the synodic phenomenon around the zodiac is referred to as "great year" (rmp.t ${ }^{3 . t)}$ which alludes to the terminology used

32 See Evans 2004: 4-7; Nawotka 2017: 52-55.

33 Neugebauer and Parker 1969: 225-240. For additional fragments belonging to the Berlin papyrus, see Hoffmann 1999: 24-26. Note that some of the birth notes (e.g. O.Narm.Dem I 22 [Menchetti 2009: 228]) use a similar format for providing the date of the nativity as the entries in the almanacs. It is given with only numbers (year, month, day, hour) instead of the traditional method. Some Greek texts of this kind employ the same system.

34 It has to be assumed that at least some astrologers engaged with materials in both languages (Ross 2020: 511-514). The final product, either the forecasts or the language of the horoscope, does not necessarily reflect the language of the sources used by the astrologer. A case in point is the socalled Old Coptic Horoscope (see n. 27 above), where the astronomical calculations are written in Greek, but the majority of the forecasts-a rare phenomenon for horoscopes-are in Egyptian. The choice of language presumably depended on the wishes of the customer and the ability of the practitioner. See Jones 1999a: 1.113-119 and 175-177 for an overview of relevant materials in Greek. 35 Neugebauer and Parker 1969: 240-241; Escolano-Poveda 2018/2019: 1-36. 
for the lunar cycle. ${ }^{36}$ The corpus to which this text belongs also contains other procedures, such as for calculating the first visibility of the planet as a morning star. ${ }^{37}$ P.Flor. 44 belongs to the same category of texts. ${ }^{38}$ These treatises could be used to produce various kinds of tables, ${ }^{39}$ and therefore also, if needed, tables with daily positions of the planets. ${ }^{40}$ But not all astrologers may have been able to use such tools. ${ }^{41}$

That is not all, however. The Sun and the Moon are not accounted for in the so-called sign entry almanacs, nor is the ascendant. The position of the Sun could probably be established through simple rules of thumb. In the framework of the Egyptian calendar, the position of the Sun changes roughly by a whole sign every century. Using the Alexandrian calendar, which was introduced under Augustus, there is almost no change in position between two instances of the same calendar date. ${ }^{42}$

The Moon, however, is a more complicated affair. The movement of the Moon is not as easily predicted, but various texts in both Demotic and Greek were

36 Ossendrijver and Winkler 2018: 382-419, esp. 386-388. The term was misread but correctly understood in the ed.pr. (see Quack 2019: 21). In relation to the Moon, it refers to a year of 13 lunar months (e.g. Neugebauer and Parker 1969: 225). Note that similar terminology is employed in P. Monts.Roca inv. 314, where the term 15.nt, which usually signifies a Full-Moon day, is used to denote the acronical rising of a planet (Escolano-Poveda 2018/2019: 24-25). This suggests that planetary phenomena were modelled on the lunar cycle; detailed knowledge of the latter must have been older.

37 It is to be assumed that they belonged to the toolbox of an astronomer capable of producing tables of planetary positions, i.e. someone with a profound understanding of astronomy. In this connection, note that Jones 2007: 311 has suggested that most astronomical tables were not produced by the astrologers themselves but supplied by more learned individuals.

38 Neugebauer and Parker 1969: 250-251. See also Quack 2016: 234-235; 2019: 21.

39 See e.g. Jones 1999b: 299-340.

40 Jones 2012: 60.

41 This is the view of Jones 2007: 311; Stockhusen 2012a: 103.

42 If the astrologer did not know this by heart, having access to a text like the one found on 0 . Stras.Dem. 521 (Neugebauer 1942: 246; 1943: 121-122) would enable him to know the zodiacal sign of the Sun for each month. The manuscript dates to the Roman period. However, an earlier date is suggested by the correlation between the month of Thoth (tpy sh.t) and Scorpio, which fits a date between the 30th Dynasty and the early Ptolemaic period for the Egyptian calendar. It is probable that the list was originally compiled in this period and not updated thereafter. In this time span, a date of composition in or close to the reigns of Ptolemy I Soter or Ptolemy II Philadelphus is most probable, at least if one assumes that the first day of the year should approximately agree with the conditions described by the text. An earlier or later date in this interval would produce too short a time span during which the correlations between the Sun and the zodiac signs are in reasonable agreement. The text is, therefore, potentially the earliest attestation of the zodiac in an Egyptian text (Neugebauer 1943: 121; Quack 2018a: 82). See Ross 2007: 166-169 for a text that possibly contains part of a procedure to establish the position of the Sun. 
available for establishing its position fairly precisely. ${ }^{43}$ P.Carlsberg $638,{ }^{44}$ for instance, is a so-called lunar ephemeris with daily positions of the Moon for the year AD 13/14, although only the period between late August and early September is preserved, i.e. the first month of the Egyptian year according to the Alexandrian calendar. The positions are given in relation to the zodiac and expressed in whole degrees. According to the editors the text was composed in close proximity to the dates covered by the tables. ${ }^{45}$ Other relevant texts include O.Berlin $30539,{ }^{46}$ which contains dates of the New Moon in the year AD 184/185, the 25th regnal year of Commodus. The text also provides the hour of this phenomenon. P.Vindob.Dem. $4876,{ }^{47}$ from Soknopaiou Nesos of the Roman period, on the other hand, provides dates and hours that could pertain to the Full Moon. ${ }^{48}$

An earlier text, P.Berlin 13146- $7^{49}$ from Abusir el-Melek, contains a list of lunar eclipses, of which the dates and the zodiacal signs are specified. The calculations are based on the Callippic cycle ${ }^{50}$ and the dates fit the interval 84-73 BC. It has therefore been suggested that the text was written a few years before this interval. Note that the papyrus is the earliest firm attestation of the zodiac in a text written in Egyptian. ${ }^{51}$ Finally, any survey of Egyptian texts relating to the calculation of lunar positions must mention P.Carlsberg $9,^{52}$ from Soknopaiou Nesos, ${ }^{53}$ which can be dated to the second century AD. The text contains a table of the first lunar days over a span of 25 years of the civil calendar, or 309 lunar months. ${ }^{54}$ The Greek P.Ryl. IV

43 An overview of texts relating to various lunar phenomena is provided by Altmann-Wendling 2018: 788-792; 2019: 219-223. See also Jones 1999a: 1.175-176; Hoffmann 2010: 236.

44 Hoffmann and Jones 2006/2007: 10-20.

45 The text uses the so-called Standard Lunar Scheme, which, therefore, is to be dated to the first century BC according to the editors of the papyrus (Jones 1999a: 1.175-176).

46 Hoffmann 2010: 233-236.

47 Neugebauer and Parker 1969: 243-250.

48 Altmann-Wendling 2018: 792; 2019: 223.

49 Neugebauer, Parker, and Zauzich 1981: 312-327 (see also Jones 1999a: 1.14). The other side also relates to similar matters; it contains predictions for the first day of every season (Parker and Zauzich 1981: 472-479), i.e. information which would be typical for any temple astronomer (see below).

50 Jones 1999a: 1.14; Hoffmann 2014: 85.

51 These are already mentioned in, for instance, the Greek P.Hib. I 27 of the early third century BC, which contains a cult calendar for the Egyptian rituals connected to astronomical events.

52 E.g. Neugebauer and Parker 1969: 220-225. Additional fragments were published by Zauzich 1974: 157-158; Hoffmann 1997/1998: 34-37. The standard treatment of the text is Depuydt 1998a: 1277-1297. For a recent comprehensive interpretation of this text, see: Depuydt 2016: 39-60 with further references.

53 See Quack 2017a: 199, n. 5.

54 See the recent note by Spalinger 2017: 377-381 on the potential origin of the 25-year Egyptian lunar cycle. 
589, which dates to the second century BC, contains a similar table, though another type of lunar cycle is used. A number of Greek texts calculate several other lunar phenomena, such as apogees and latitudes. ${ }^{55}$ What all of these texts demonstrate is that the knowledge to calculate the path and phases of the Moon and other celestial bodies was amply available in those environments where one expects to find astrologers. ${ }^{56}$ Even if an astrologer lacked the capacity to produce such texts himself, he could surely consult them.

Finally, the ascendant would need to be established. The zodiac sign in which the ascendant is located changes approximately every second hour. However, the Sun moves through the zodiacal signs by roughly one degree per day. Consequently, at the same hour a month later another sign will rise on the eastern horizon. The use of seasonal hours in antiquity complicates matters if the ascendant is to be determined accurately for the hour of birth as specified by the client. Seasonal hours vary in length depending on the date and geographical latitude. Thus, the astrologer would need to take account of these factors when establishing the ascendant. Indeed, certain texts explain the variation of the length of the hour throughout the year. ${ }^{57}$ Access to these texts, or rather knowledge of how they functioned, may not have been available to all, but being able to establish the correct hour was one of the main responsibilities of an Egyptian astronomer, and it was a type of knowledge prestigious enough to deserve space in several inscriptions of owned by astronomers (see below).

Following A. Menchetti, who edited OMM 423, the "horoscope 〈book〉" could have been a sort of table that provided the rising times of the zodiac signs or similar. ${ }^{58}$ Such a tool would obviously smoothen the process considerably and facilitate the precise computation of the ascendant. Yet, due to the wide use of the term "horoscope" other kinds of texts could have been implied. ${ }^{59}$ The "great list of regnal year 3"60 could have been a "sign entry almanac" according to the ed.pr. ${ }^{61}$ But since it is specified as pertaining to a particular year, there are several other

55 See e.g. Altmann-Wendling 2019: 221-222.

56 Note that there are examples of horoscopes that only contain whole sign entries for the planets but can provide longitudes for the Moon. Examples include O.Neugeb. 1-4.

57 Naether and Ross 2008: 50-90; Hoffmann 2017: 135-153.

58 See Jones 1999a: 1.283; Heilen 2020b: 257-258.

59 Cf. Heilen 2016: 534; Giseler Greenbaum 2020: 443-444 and 447.

60 Menchetti 2009: 232 suggests that the name attributed to the list signifies one of the local practitioners who owned the table in question. This is of course a prudent assumption but one cannot but wonder if the text in fact was not attributed to the great sage associated with astrology. Although he is not primarily associated with composing almanacs, Petosiris is connected to the elementary astrological teachings regarding the celestial bodies (Heilen 2015: 48), and knowledge of these could enable the computation of such tables.

61 Menchetti 2009: 232. 
types of texts to which it may belong, such as a monthly almanac with planetary positions covering a particular year. ${ }^{62}$ Here P.Lond. I 130, a Greek horoscope, should be mentioned, which, similarly to OMM 423, refers to equipment to be used in an astrological procedure. The text was compiled in Hermopolis by a certain Titus Pitenius for someone called Hermon. In the preamble, the practitioner boasts about having used an astronomical table compiled by the Egyptians of old, a so-

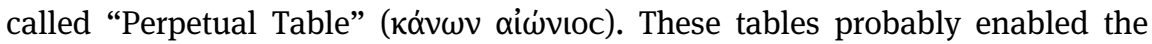
astrologer to calculate planetary positions down to at least a degree, but their exact content and arrangement remain elusive. ${ }^{63}$

A. Jones has suggested that even without many of the texts described above, a person with access to the most basic of tools, a sign entry almanac, would have needed very little astronomical knowledge to cast a basic horoscope. ${ }^{64}$ Thus, access to written materials of the kind described above, such as various almanacs and tables containing rising times, would have been a primary concern.

\subsection{Establishing Forecasts}

Focussing on a few so-called planetary astrological texts, i.e. those which primarily rely on the position of the seven planets in the zodiac, it can be noted that they, similarly to the horoscopes, represent different levels of astrological advancement. One can hypothesise that the different manuals also required different levels of astronomical knowledge if they were to be used to their full extent. The simplest version of an astrological manual of this type is represented by the Roman-period P.Berlin $8345^{65}$ from Soknopaiou Nesos. Of this text, only part of the systematic catalogue is preserved, that is, the section with a systematic list of the configurations of planets, zodiacal signs and their subdivisions with the accompanying forecasts. Usually each configuration produced a series of prognostications. The simplicity of P.Berlin 8345 manifests itself in the fact that only a planet's position in one of the places of the Dodecatropos is considered. Even the simplest horoscopes provide more information than that. From what is preserved, the text does not appear to consider whether a birth was nocturnal or diurnal, ${ }^{66}$ while this information was-as already stated-part of the standard information of

62 See e.g. Jones 1999a: 1.175-177.

63 Heilen 2020b: 260.

64 Jones 2007: 311; Jones 2012: 60; Stockhusen 2012a: 103.

65 The ed.pr. is furnished by Spiegelberg 1902: 28, pl. 97, while the first complete translation and commentary is Hughes 1986. See Quack 2008: 368-370 for an updated translation into German. 66 It is of course conceivable that the forecasts in the systematic catalogue were divided into nocturnal and diurnal sections, introduced by a heading at the beginning of each such section and 
a horoscope. The only thing the astrologer had to do once he had the standard information for a horoscope in front of him was to take note of the zodiacal sign of the ascendant. Proceeding in counter-clockwise fashion, he could then establish in what places of the Dodecatropos the planets were located.

The standard simple horoscope does not contain enough information to make full use of such astrological manuals as the three manuscripts P.Carlsberg 81, P.Carlsberg 89, and PSI inv. D $34^{67}$ from Roman Tebtunis. In the preserved part of its systematic catalogue, the main factor upon which the prognostications are established is the relation between a planet and one of the 12 places of the Dodecatropos. But the text also considers whether it was a nocturnal or diurnal birth along with the planetary dignities (qnhy.t) ${ }^{68}$ and the lots. ${ }^{69}$

The text by and large follows the same approach as found in the doctrines of the Graeco-Roman astrologers. It incorporates, for instance, the exaltations, the planetary houses, and trines. Given that the text contains a table of terms, also the terms are considered for establishing prognostications from the planetary positions. From what is preserved of the text, the phraseology suggests that it did not matter whether a planet was in its house or in its exaltation: it would by and large produce the same outcome; however, the absence of a planet from its house or its exaltation was significant. $^{70}$

For some dignities, a regular horoscope would do. This would be the case for the trines, if they are defined in terms of whole signs, and the planetary houses. Yet to determine the exaltations or the terms, more detailed positional information would be required. Such information is only preserved in the so-called elaborate or deluxe horoscopes, in which the longitude of a planet in a particular zodiac sign is registered. The Egyptian astrologers at Tebtunis, or at least some of them, were clearly expected to perform more advanced astrological consultations that required more skills than implied by the majority of the preserved horoscopes from Egypt. In order to produce a more advanced horoscope the astrologer could not simply resort to the "sign entry almanacs" but needed to consult the exact position of the celestial bodies, or to calculate them himself, for instance by employing

that this division is not apparent in the subsection. There is, however, no evidence that this was the case.

67 Winkler 2016: 247.

68 See Winkler 2016: 256-257 for the term in question and Gieseler Greenbaum 2020: 462-464 for the dignities.

69 See Gieseler Greenbaum 2016: 279-335 for the concept of the lots in Graeco-Roman astrology. One fragment talks about finding the Evil Daimon ([p; $[g y\rceil n g m$ p sšl $n$ ms.t=f). If correctly understood, this is a lot situated $180^{\circ}$ opposite the Lot of Daimon.

70 Winkler 2016: 255. 
so-called primary tables. ${ }^{71}$ It is clear that such documents were available in the temples, such as the one in Tebtunis, and that they were written in both Demotic and Greek. ${ }^{72}$

The astrologer who used the astrological manual known as P.Carlsberg 420 (see below), as far as can be judged from the preserved fragments, would not have been successful only using the simplest of methods. For example, the manual establishes predictions based on the presence of planets in their terms. ${ }^{73}$ For this, the knowledge of exact longitudes would be necessary. Even if the user of the manual did not know the terms by heart, he could have consulted a table of terms on a separate sheet of papyrus, such as that found in P.CtYBR $1132 .{ }^{74}$ As the astrologer looked through the systematic catalogue, the sheet (or in fact shorter scroll) could function as a handy reference tool assuming the horoscope only contained the longitudes. It would also assist in writing down the position in a horoscope, if the terms were noted there as the case is with, for example, O.Ashm.Dem. 633.

Other astrological texts employ different operating principles. ${ }^{75}$ These demonstrate that a variety of hermeneutical methods were available to decipher the positions of the planets and also that varying efforts were put into the casting of nativities. The reason behind the different methods is not always easy to grasp. The complexity of a horoscope must to some extent have depended on the financial means of a client and on his or her preparedness to remunerate the practitioner. As already stated above, most horoscopes were of the basic kind. These were undoubtedly cheaper to produce than the more lavish ones. ${ }^{76}$ Personal investment in

71 Jones 2007: 311.

72 One example is the above-mentioned P.Carlsberg 32 (see Quack 2019: 21). See also Jones and Perale 2011: 39-50; 2012: 308-343; Ryholt 2018: 144. The fact that the Egyptian priesthood in some capacity was the intermediary for disseminating Babylonian astral knowledge to the Greek speaking world (e.g. Jones 1999b: 335-336; Hoffmann 2014: 80-88; Ossendrijver and Winkler 2018: 410-411; Escolano-Poveda 2018/2019: 29-31) means that the presence of such materials is not surprising.

73 A formula introducing the predictions can read: "The one who was born when Mars was in the terms (lit. part) of Mercury” (psy-ms=w r Hr-tšy hrr t3 dny.t $n$ Swg; ...), though a host of other parameters are taken into consideration throughout the manual.

74 The heading of the table is largely lost but contains the word dny.t, "terms".

75 For the manuals that base their forecasts on the Sun and the Moon in the decans, as part of the zodiac signs, the practitioner must probably have relied on the so-called elaborate horoscopes; the position of the Sun would be easy to find out once the date was known, while the Moon, depending on the hour and the position among other factors, can be found in up to three different decans during the 24-hour day. Thus, its daily motion would have to be considered and determined down to the hour.

76 Heilen 2020a: 493. The fact that horoscopes of varying complexity can be found together on the same piece of papyrus (e.g. P.Oxy. XII 3298) favours the view-although not ineluctably so-that an 
the art as well as astronomical skills may also have played a role, as already suggested by Jones. ${ }^{77}$ The next question one can ask is therefore what can be determined about who had access to such knowledge.

\section{Astrologers and Access to Astral Knowledge}

Astronomers possessed the skills for making a prognostication of an individual's future by means of the planets (see below), but were the priests who were engaged as temple astronomers, along with the hierogrammetus, the only ones who were able to do so ${ }^{78}$ And is it possible that those engaged in casting horoscopes also possessed specialist knowledge in other areas? Were others besides these priests allowed to acquire such skills?

O.Narm.Dem. II 82.1-7 is one of many texts from Narmouthis relevant for an enquiry into the social world of the astrologer. Although the precise nature of the document remains a matter of debate, it relates to an astrological consultation. The text is directed to an astrologer or perhaps an aspiring one. It begins as follows: "Another matter in relation to waking in the great place. When you write and arrange your astrological board and your calculations, do not allow the young boy to discover your calculations"

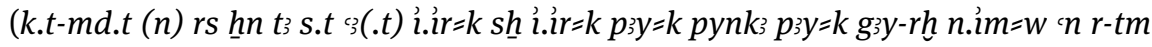
di.t ir pзy hl gm pзy=k g;y-rh).

From the phrasing of these lines, it is obvious that the astrological consultation

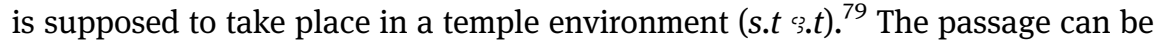
interpreted in two ways. It can be understood either to refer to an astrological consultation in which a practitioner is casting the horoscope for a young client or

astrologer often could compile more complex horoscopes than he in fact usually did. A motivation would naturally have been a higher profit.

77 E.g. Jones 2012: 60.

78 See $n .105$ below.

79 The location is connected to various cultic activities (Smith 2005: 228). That the inner parts of the temple were used for undertakings not directly connected to the cult, such as magic and astrology, is also seemingly confirmed by a number of Greek texts regarding such matters (see e.g. Moyer 2011: 209 and 254). That such business can be regarded as part of the priest's "private affairs" is further suggested by O.Narm.Dem. I 27.12-15, which gives the practitioner instructions on how to handle the economic recompense that came with such a procedure. Menchetti 2009: 223, n. 5 , suggests that the money was paid in instalments, part of the sum before the procedure began and then two more, perhaps when the horoscope was presented, and, possibly, after the consultation. The common image of a Roman period astrologer's ability to survive is based on whether he was able to collect fees for his services (Rives 2011: 685). See also Hübner 2020: 318. 
as describing part of the teaching process of astrology. In the latter case, the young boy would refer to the apprentice, who is not yet allowed to learn all the steps of such a process. In this first scenario, the quoted passage can be understood as assuring that astral knowledge was not disseminated to the populace, for instance by not revealing the method for computing planetary positions or check their astrological significance in handbooks. The interaction between the astrologer and the customer would be limited to delivering the forecast, and perhaps illustrating the positions with a pinax. The preparations were to be kept secret, and therefore the text on the ostracon can be viewed as an admonition to keep the knowledge within the group of practitioners. One can imagine that in this way competition could be kept at bay and an "authoritative mysticism" 80 vis à vis the customer could be maintained.

In the case of the second interpretation, that it concerned the relation between a master and an apprentice, the trainee would only be allowed to obtain insight into the working methods of astrology once he was ready, having reached the appropriate stages of his sacerdotal training. The priests are known to have gone through several steps in their education. One source that gives insight into this process and at the same time refers to astral knowledge is the so-called Book of the Temple. ${ }^{81}$ In one section of the text that has been discussed thoroughly by J. F. Quack, one learns that priestly candidates of the higher orders (children of the prophets, the lector priests, and the superior priests $\left[w^{c} b . w w_{3}\right]^{82}$ ) had a partially shared schooling, ${ }^{83}$ and that the highest-ranking among them, the children of the prophets, would go through additional stages.

80 Cf. Dieleman 2005: 185-284. The performance could also involve some more dramatic elements (Gury 1996: 255-256). Rives 2011: 681 stresses that further social authority came with possessing otherwise inaccessible knowledge. That was surely the case for freelancing practitioners and cannot be denied in the case of the temple servants either, who already would have possessed such means through their sacerdotal role.

81 E.g. Quack 2003: 11-18 and Quack in this volume.

82 de Meulenaere 1955: 219-225; Quack 2002b: 164; Smith 2009: 360; Wegner 2011: 117, n. 2; Smith 2017: 451; Leroux 2018: 10-11 and 207. The title $w^{c} b$ s also appears in conjunction with that of a prophet (hm-ntr) in O.Hor 31.1-2. The connection is also attested at, for instance, Dendara (see e.g. Derchain-Urtel 1989: 171, 175-176, 188, and 193). Such priests are, furthermore, encountered on a number of statues of the Ptolemaic period from various parts of Egypt, e.g. Cairo CG 689 (Zivie-Coche 2004: 140-181); BM EA 48038 (Birk 2020: 418). A few papyri containing the Books of Breathing also belonged to such dignitaries, e.g. P.Louvre N 3179; 3291 (Herbin 2008: 205-207). The scribe who copied the so-called Book of the Fayum (Beinlich 2014), was a $w^{c} b$ ? and a "priest who conducts the rituals" ( $w c b$ nty ir hny) (see Ryholt 2019: 507, n. 21). The title is attested up until the mid-fifth century AD in connection to the goddess Isis at Philae (Graf.Phil. 365).

83 Quack 2002b: 161 and 164-165. 
These stages include an acquaintance with various forms of cultic knowledge as well as reading and writing religious scriptures. In the penultimate stage, it seems that medicine was on the curriculum. ${ }^{84}$ In the fourth and final stage of their education, the candidates were supposed to learn, among other skills, "eclipse omens" (shn iby.t) - though the passage can also be read as "omens and eclipses". 85 "Eclipse omens" does not necessarily imply a deep understanding of the astronomical mechanisms behind these phenomena. The passage could refer to making forecasts based on observed eclipses. It could in theory be limited to access to texts that explain the outcome of eclipses such as the "Vienna Papyrus on Eclipses and Lunar Omens". ${ }^{86}$ As seen in the inscriptions from Dakke and Philae (see below), however, knowledge of the timing of eclipses was stressed. Being able to predict and understand eclipses entailed a higher level of astronomical knowledge. It is possible, therefore, that the passage describes the candidates going through this step of education as obtaining training in advanced astral knowledge, or at least it could be understood as such in later times when there were additional techniques pertaining to celestial divination.

Considering that the text was composed before the advent of natal astrology, ${ }^{87}$ it is possible that this form of divination was later subsumed under the heading of omens ${ }^{88}$ or was even understood as an extension of "eclipse omens". It is of course also imaginable that there was a stark division between making forecasts on the basis of eclipses and regular natal astrology. The former concerned political events and the well-being of the country, delicate matters that may not have been entrusted to just anyone, thus being reserved for the highest stratum of temple servants. One would then also expect a similar limitation to apply to the so-called Sothis texts, which make the same kind of prognostications as the eclipse omens, to a small number of individuals at the top of the temple hierarchy. Natal astrology could have been be a pursuit that anyone with the right skillset would be allowed to engage in, while access to universal astrology or celestial divination was more restricted. Considering the numbers of

84 Quack 2002b: 167-168.

85 Ryholt 2005: 162, n. 97.

86 The ed.pr. was furnished by Parker 1959. Quack 2017b: 201-203 has provided an updated translation of part of the text. See also Altmann-Wendling 2018: 794-799. Other similarly relevant texts are discussed by Stockhusen 2012b: 457-463; Quack 2017b: 198-206. Texts concerning various Mercury phenomena served the same purpose. It is possible that the planet was chosen as a good focus point for predictions due to its seemingly irregular motion across the sky.

87 Quack argues cogently that the text is older than the manuscripts in which it is found.

88 Shn can be used to denote the "influences" of various stellar configurations (Hughes 1986: 58), but the term is also used in the so-called New Kingdom Menologion (Vernus 1981: 89-124). 
Sothis texts surviving from, for instance, Tebtunis, this hypothesis seems difficult to maintain, however. ${ }^{89}$

The same can be inferred from P.Berlin 13146-7, whose recto side treats lunar eclipses, while the other side, the verso, concerns calculations of the first day of the first season throughout the year. ${ }^{90}$ The manuscript may have belonged to a prophet or the like, but more likely it comes from an "astronomer's workshop". Recall that the "Book of the Temple" does not specify whether the "eclipse omens" of the fourth stage of education deal with solar or lunar eclipses, or both. The second text on P.Berlin 13146-7 can be viewed as an appropriate part of any temple astronomer's toolbox (see below). Though the recto may have been discarded by the person who inscribed the verso, he did have access to that information. This text could thus indicate that some regular astronomers, and not only the prophets or other higher-ranking temple officials, had access to texts about eclipse prediction. Perhaps, therefore, the text of the "Book of the Temple" should be understood as describing what the prophet was expected to learn without any claims that other categories of priests were excluded from gaining such knowledge. Other sections of the treatise also make clear that the particular tasks ascribed to specific offices in the temple were often shared. Thus, astral knowledge does not seem to have been a secret within a fairly small "in group".

\section{Astral Knowledge and the Temple}

One question that has to be answered is who was the primary practitioner of astrology in a temple environment. As mentioned, it is natural to assume that the temple astronomers ${ }^{91}$ would be able to perform such consultations. ${ }^{92}$ But before

89 The papyrus PSI inv. D 39 from Tebtunis contains two astrological texts. One is a natal astrological manual that bases its predictions on the presence of the two luminaries in various decans, while the second makes predictions based on the appearance of Sothis. Each text occupies one side of the papyrus roll. Though it appears as if the two texts were written by two different individuals, it is conceivable that the two could have been used by one and the same practitioner. The latter text may have been "inherited" and its back reused for the other. Perhaps the so-called Sothis text was discarded and not of any interest to the individual who wrote down the natal astrological text, but in theory he could have had access to such knowledge through the "backside" of his manual. Among Graeco-Roman astrologers, for example Hephaestion of Thebes, it seems that engagement in both these spheres was common.

90 See $n .49$ above.

91 People with various titles that can be designated as astronomers are attested from the Old Kingdom (5th Dyn.) until the Roman period (see Fissolo 2001: 15-21; Lull 2004: 63-78; AltmannWendling 2018: 782-788).

92 Jones 1994: 42-43; Dieleman 2003: 278. 
embarking on an exploration of this ostensibly obvious hypothesis, it must be pointed out that the English translation of the most common Egyptian title designating such people, wnw.ty in older texts and imy-wnw.t in younger ones, ${ }^{93}$ as "astronomer" is a slight misnomer. The title is literally "Who is in the Hour" and describes by and large the duties of this person. ${ }^{94}$ The primary responsibility of this priest was to establish the length of the day, the seasons, the year, and the hour when the cultic rites were to be performed ${ }^{95}$ as well as, for instance, finding the time when the inundation was supposed to start. ${ }^{96}$ Being responsible for knowing and announcing the hour when the rituals were going to be performed, he needed to know the length of the seasonal hours. ${ }^{97}$ It seems that this was by and large an observational duty, as is suggested by preserved astronomical instruments, ${ }^{98}$ unlike the establishment of the positions of the celestial bodies on a horoscope. ${ }^{99}$ However,

93 The Demotic title can also be written as wnm-wnw.t (Quack and Ryholt 2019: 167), which reflects the tradition mentioned by Horapollo (1.42). Graf.Phil. 65.4-5 can also be added to the examples provided by Quack and Ryholt.

94 See e.g. Derchain-Urtel 1989: 178-180; Daoud 1993: 262-264; Quaegebeur 1995: 150-151; Vittmann 1998: 322-324; Fissolo 2001: 15-24; Dieleman 2003: 278; Birk 2014: 83-84; Winkler 2016: 270; Altmann-Wendling and Stockhusen 2020: 110-113. Three other titles that designated astronomers are wnwn (see n. 128 below), imy-p.t, and imw-p.t (von Lieven 2020: 423-424 and in this volume).

95 The inscription found on the 26th Dynasty palm staff (Berlin 14084) of the astronomer (imy-wnw.t) Hor (Borchardt 1899: 10-17) is an excellent illustration of these tasks: "The one who is vigilant ( $r s-h r r)$ concerning the conduct (sšm) of the feast, who places everything in its hour (di.t $h r$ $n b$ hr wnw.t=sn)".

96 Sauneron 1959: 36-41; Osing 1985: 100-101; Török 2009: 459-460; Birk 2014: 83 and 86; von Lieven 2020: 423-425.

97 For time reckoning in general, see the recent treatments of von Lieven and Schomberg 2020: 52-89; Symons 2020: 14-51.

98 von Lieven and Schomberg 2020: 52-89; Symons 2020: 14-51. See also e.g. Menchetti and Pintaudi 2010: 269-277; Hoffmann 2016: 342-375. Von Lieven 2020: 423-424, n. 28, stresses the observational character of the astronomers by pointing to the fact that the title (wnw.ty/imy-wnw.t) can be written with an eye determinative ( $W b$. I: 316.2 and 317.9). The temple roof is commonly regarded as the area where the astronomers made their observations (Wild 1970: 122-125; Derchain-Urtel 1989: 178; Fissolo 2001: 18; Jacquet-Gordon 2003: 5) as seems to be the implication of, for instance, the stela Flor. inv. 6371 (Bosticco 1965: 42-43). An observatory has been found at Meroë (Depuydt 1998b: 171-181; Logan and Williams 2000: 59-82), but the edifice is not situated on the roof. At Karnak there are at least three graffiti of gnomons (Trauneker 1993: 89, n. 16) among depictions of other temple paraphernalia at the seventh pylon (south face, east massif) close to the Bark Shrine of Thuthmoses III. These could indicate astronomical activity (timekeeping) in the vicinity of these depictions, although it is more plausible that they merely indicate that astronomers had been there in relation to a procession. I thank Chiara Salvador for sending me the images of these graffiti (Traunecker Archive, University of Oxford: Quire 5, R4.18-19, 21).

99 Jones 2007: 310. 
texts also indicate that prediction must have been part of the duties of the astronomer (see above), ${ }^{100}$ for instance, when establishing the length of priestly rotas. ${ }^{101}$

Perhaps the astral knowledge of this temple functionary only covered timing. But most temple astronomers probably possessed knowledge about the skies that goes beyond the ability to identify through observation the five planets that were known in Ancient Egypt. The description of, for instance, Clement of Alexandria (2nd-3rd cent. AD) makes this clear. His account is generally taken to be an idealised description of the office of temple astronomer during the Graeco-Roman period, but it may also be valid for earlier times.

In a famous passage from book six of his Stromateis, the author discusses the realms of Egyptian "philosophy" as displayed by the knowledge of the indigenous priests. ${ }^{102}$ He describes the different areas of wisdom by pointing to various books whose content they were supposed to know. Included in his enumeration is a priest referred to as the Horoscopos (ம்оско́лос), ${ }^{103}$ literally "Hour Watcher", who bore

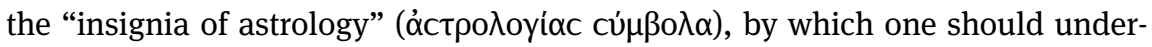
stand "astronomical insignia", a horologion and a palm rod. Clement's description of the temple astronomer is well known from Egyptian images. ${ }^{104}$ The Horoscopos was supposed to know by heart four Hermetic books. These concern (1) the arrangement of the bright fixed stars; (2) the positions of the Sun and the Moon and the five planets; ${ }^{105}$ (3) conjunctions (syzygies) and luminous appearance (phases)

100 Hoffmann 2016: 342-356.

101 Altmann-Wendling 2018: 789-790.

102 See Quack in this volume.

103 Clem.Strom.6.4.35. The title ஸ́роско́лос appears to be particularly connected with Egyptian temple servants and is used elsewhere in the literature for a person engaged in astrological activities, e.g. Gal.11.798 (2nd cent. AD). The term is also found as a designation for diviners in the

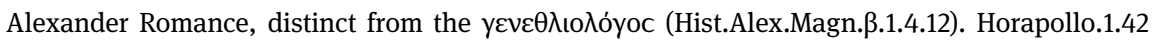
and 1.49 (5th cent. $\mathrm{AD}$ ), on the other hand, is in line with later lexical traditions, where the term designates a person preoccupied with determining the time rather than someone engaged in the casting of nativities. Note that the title does not appear in the papyri as a designation for temple astronomers. There, for instance, $\dot{\omega}$ poגóyoc is attested in this function but only in texts from Roman Tebtunis. The latter term also found its way into the literary tradition, e.g. Porph.Abst.4.8, but without being a clear reference to someone who casts horoscopes (although of course this could have been implied). The Coptic term peqкдо rnor, literally "who appoints hours", which should be translated as "astrologer" or "caster of horoscopes", is akin to both Greek expressions. See Hübner 2020: 298-303 for the various terms designating astrologers. Papathomas 2006: 21-22 lists the attestations of the term áctpolóyoc in the Greek papyri.

104 E.g. Birk 2014: 84; Pfeiffer 2018: 683. Astronomers could also be depicted carrying other instruments, such as a "trident" (Birk forthcoming).

105 See Winkler 2016: 271, n. 88. The phrase is actually found among the books carried by the hierogrammateus. Although there is an error in the text, it must be assumed that this temple 
of the Sun and the Moon; and (4) rising times. According to O. Neugebauer the four books are also attested in a temple context, namely in the title catalogue of the library of the Edfu Temple. ${ }^{106}$ An Egyptian treatise designated as "Knowing the Motion of the Two Shining Ones (viz. Sun and Moon), Ruler(s) of Stars" (rh nmt.t $n(. t)$ hij.ty hq? $\left.q_{3}(. w) h_{3} b_{3} s . w\right)^{107}$ was thought by Neugebauer to correspond to the four scrolls mentioned in the Greek text. ${ }^{108}$ If correct, these works cannot be Greek but must be "proper" Egyptian ones.

Although it is not entirely evident what is implied by the content of all the texts mentioned by Clement, the titles suggest a rather broad understanding of astronomy. The fixed stars are known to have played an important role in Egyptian religion. Nevertheless, exactly what is meant with the "order" or "regularity" ( $\tau \dot{\alpha} \xi ı c)$ of the two luminaries and the five planets cannot be known for certain, but it may well refer to their periodic motion through the zodiac. The topic of syzygies and phases of the Sun and Moon is more straight-forward, and probably involved

functionary also had access to such knowledge (e.g. Evans 1961: 190; Winkler 2016: 272, n. 89), since they possess this capacity in, for instance, P.Hib. I 27 and PSI VII 760.

106 Neugebauer 1942: 238, though it is to be noted that Neugebauer misread the titles slightly (see the following note). See also von Lieven 2020: 413.

107 Edfou III 351.4. See von Lieven 2000b: 49-50, n. 172; Altmann-Wendling 2018: 787, n. 52, for the reading; Wagner 2018: 117-125 for the term h333s.w. An epithet of Imhotep in Dendara (XIII 5860): "Who speaks that which is to come before it is brought about; who knows the course of the stars" (dd iy.t $n$ in (.t)=s rh nmt.t hisbss.w) (Cauville 2010: 19) is surely related just as is the description of Thoth: "Who reckons the sky and calculates its stars" (hsb p.t ip h3s $b_{3} s . w=s$ ) (Wagner 2018: 117). The inscription from Edfu can be seen as parallel to one found on a gnomon (Berlin 14085) belonging to the astronomer Hor of the 26th Dynasty (Borchardt 1899: 10-17): "The one who knows (rh) the motion (nmt.t) of the two discs (itn.wy) and every star in its place ( $s$; $n b r d m y=f)$ ". Stockhusen 2012b: 460 proposes that the reference to the two luminaries could imply knowledge of how to calculate eclipses, although admittedly such a connection cannot be substantiated.

108 Jones 1994: 43 rightly points out that the books presented by Clement appear to have very little to do with what can be called astrological practices. Whether the "books of the astronomers" ( $n$ s $\mathrm{dm}^{c} . w(n) n_{3}$ wnm-wnw.wt) mentioned in P.Carlsberg XI 10.2, which contains a longer socalled find-note of an astrological text attributed to Imhotep, refers to such treatises or not is unclear. Note, however, that Quack and Ryholt 2019: 162 and 167 translate the phrase as "the books of the astrologers". The treatise mentioned in the introductory story is referenced later on in the text as that of Imhotep ( $\underline{d} m$ c (n) Iy-m-htp), the son of Ptah, the Great God, and seems to be labelled as a "teaching concerning every matter pertaining to the sky" (sb3 hr md.t [nb.t nty $p h]$ ] $r]$ $t_{3}$ p.t). We furthermore learn that the great sage explains numerous "drawings" $(t k)$, which the editors assume could mean "diagrams" (Quack and Ryholt 2019: 169). Even if the exact meaning of the phrase is unclear, such a reading would accord better with a table of some sort usually connected with astronomical rather than astrological content, though admittedly the boundary between the two categories of texts is blurred, and what is left of the technical treatise is beyond doubt astrological in nature. Note, however, that the so-called Vienna Papyrus on Eclipses and Lunar Omens (see n. 86 above) contains numerous drawings. 
knowledge of such astronomical texts as the ones described above. The term rising times is again more general. This may refer to the first visibility of planets or the decans. The rising times of the zodiac signs or Sothis cannot be excluded either. Whether Clement's account can be taken to mean that these astronomers used Babylonian methods, ${ }^{109}$ as required for the casting of horoscopes, or that they were only schooled in Egyptian "religious astronomy"110 as contained in the "Book of Nut" ${ }^{\text {"111 }}$ as suggested by Neugebauer and K. Ryholt, ${ }^{112}$ cannot be firmly determined. The latter scholar also includes the astrological treatises as part of this functionary's competence; such works appear to have been abundant in a temple environment.

Having access to such knowledge of the skies, the temple astronomer-at least in theory-could engage in astrological practices by casting horoscopes. ${ }^{113}$ But would such a person really pursue divination? Scholars have assumed that temple astronomers could act as diviners (of sorts) already in earlier periods of Pharaonic history. It has also been suggested that it was the temple astronomers who were primarily responsible for dealing with the hemerological composition known as the "Book of Good and Bad Days". ${ }^{114}$ Even if these are not divinatory per se, according to strict definitions, they deal with a set of related practices. ${ }^{115}$ In this connection, the so-called Israel Stela of Merenptah (13th cent. BC) ${ }^{116}$ is relevant. It mentions individuals who observe stars and winds as having uttered a kind of prophecy about the pharaoh's victory against his enemies. The fact that "Books of Astronomers" are mentioned in relation to astrological writings in the Demotic P.Carlsberg XI 10.2, a story about the discovery of astrological works, also suggests that the temple astronomers were engaged in astrological activities. ${ }^{117}$ The question posed above should therefore be answered in the affirmative. Astronomers did participate in divinatory practices with the techniques that were at their disposal. Depending on rank and locality, among other factors, they could serve a wide array of clients. The royal court was clearly interested in predictions about the future, but hardly every practitioner would have been required to divine for the king. Yet

109 See Stockhusen 2012a: 85-105 for an overview of Babylonian astronomical knowledge in materials from Roman Egypt.

110 von Lieven 2000b: 188-190.

111 von Lieven 2007.

112 Neugebauer 1942: 239; Ryholt 2005: 160. See also Jones 1994: 43.

113 E.g. Török 2009: 460.

114 Cumont 1937: 124; Sauneron 1960: 66; Jones 1994: 43; Dieleman 2003: 278-279.

115 Leitz 1994.

116 KRI IV 12-19 (e.g. Brunner 1973: 25-30; Quack 2002b: 168-169).

117 See n. 108 above. 
universal forecasts could surely be of relevance more locally as well. ${ }^{118}$ After the introduction of horoscopic astrology, an innovation that spurred advances in astronomy, ${ }^{119}$ it can be assumed that astrology was part of their repertoire.

\section{Inscriptions of the Astronomers and Astrologers?}

\subsection{Temple Astronomers}

There are several more or less detailed descriptions of timekeeping from the Middle Kingdom and onwards. ${ }^{120}$ From the Late period, for instance, a stela belonging to Ankhhor (Montgeron 2007.4), the Chief Astronomer (hry (imy)-wnw.t/mr-wnw.ty), adds the extra information that he was one "who knows the coming forth (viz. heliacal rising) of Sothis" (rh $\operatorname{pr}(. t)$ Spd.t). His son, Hersenef, who is also mentioned on the stela, is styled in a similar way. ${ }^{121}$ Other Late period monuments can be less informative. The stela of Ashaihy from the 30th Dynasty is more modest in terms of information. It only states that the owner was a "knower of the skies" (rh p.t). ${ }^{122}$ The contemporary so-called Dattari Statue is an example of an inscription that unveils the responsibilities of the owner of the monument. ${ }^{123}$ The person who commissioned the inscription was a prophet (hm-ntr) and calls himself "the one who knows the hours with the help of the

118 For example, market prices of important commodities, such as crops, may have been predicted based on events expected to take place in the coming year, similarly to Mesopotamian practices (e.g. Ossendrijver 2019: 53-78). Nile floods and agricultural yields are mentioned in the Egyptian materials pertaining to universal predictions. P.Oxy. LXV 4473 specifically makes predictions on the height of the inundation based on stellar configurations. Such information would have been invaluable to the temple and its sustenance. Additionally, it appears that P.Cair. II 31222 from Tebtunis was produced for a particular year: AD 134 (see n. 197 below). Since the text was found at the site, one can envision that it was related to the affairs of the temple rather than being destined for the Roman authorities.

119 Gieseler Greenbaum 2020: 443.

120 E.g. Willems 2007: 43 and 52-54 provide an example from the Middle Kingdom, the biographical inscription of Djehutynakht, while New Kingdom examples include Amunemhat (e.g. von Lieven 2016: 207-231).

121 Dhennin 2012: 67-78, but see Birk forthcoming. That observing or predicting the rising of Sothis was part of the astronomers' standard repertoire can also be inferred from a passage from the Myth of the Sun's Eye (P.Leid. I 384 x 15-16): "They are concerned about you, just as the astronomers are about Sothis" (st wbs=t mi-qdy nз imy-wnw.wt [r] Spd.t).

122 Depauw 2001: 1-2.

123 See Guermeur 2005: 304-306 for the text in question. 
gnomon and the wnšb" (rh wnw.w(t) m mrh.t ḥnc wnšb), ${ }^{124}$ but is not labelled as an astronomer. These inscriptions display astronomical knowledge, and that the astronomers engaged in both observational and perhaps predictive astronomy related to timekeeping, but that they hardly ever dealt directly with divination or astrology. Such rather terse accounts, however, should not be viewed as encompassing the whole range of the astral knowledge of the person in question. They are rather an expression of an aspect that the commissioner of the inscription chose to emphasize.

Knowledge of the skies could also be expressed by more visual or material means. "Zenon" was a high-ranking priest in Coptos and a courtier of Ptolemy II Philadelphus. ${ }^{125}$ Although he lacks any titles pertaining to timekeeping, a steatite gnomon (UC 16376)-an emblem of temple astronomers ${ }^{126}$-belonged to him. ${ }^{127}$ The instrument displays acquaintance with observational astronomy. One can only speculate about the possible connections with his position at the Alexandrian court in a time when the astral sciences had become more fashionable.

A handful of inscriptions from the last centuries before the turn of the Common Era, for instance from Thebes, record the title of astronomer or even chief astronomer. ${ }^{128}$ These inscriptions only rarely disclose much information about their role as time keepers or anything that can be directly interpreted as pertaining to celestial divination or astrology, ${ }^{129}$ which does not preclude that they engaged in these arts. A reasonable explanation would be that astrology, or perhaps specifically casting personal horoscopes, was not part of the ritual duties of these priests. The latter duties were the ones stressed in the inscriptions. As ritualists in a temple they had other obligations, and if one was moonlighting as a diviner, this must have been regarded as secondary to his cultic responsibilities.

124 For this object, see e.g. Jasnow 2010: 242.

125 See Moyer 2011: 90, n. 22, for references to monuments of this dignitary as well as to discussions on how to read his name.

126 See Birk 2014: 81-87 for the stylistic features connected with statues of astronomers.

127 Guermeur 2003: 290-291; Symons 2020: 18-19.

128 Birk 2014: 81-87.

129 Cairo JE 43652 (Birk 2014: 81-84; Altmann-Wendling and Stockhusen 2020: 111; Birk forthcoming) announces that the owner of the statue, a Chief Astronomer of Amun (hry imy-wnw.t $n$ Imn), worships the first lunar crescent as it appears, which has been interpreted as referring to establishing the correct time for cultic acts. He also claims to be the one who announces and divides the hours on another statue belonging to him. 


\subsection{A Stargazer from the Fayum}

Some of the astronomers went beyond stating that they had this title by providing a more or less elaborate description of their area of competence. One text is inscribed on the incompletely published statue belonging to Senty, son of Pensuchos (Cairo TR 25/11/18/3), ${ }^{130}$ who was most probably active in the Fayum. He was an "astronomer ${ }^{131}$ of the Domain of Souchos ( $n$ pr Sbk)". The text is not the only evidence through which one can see that the owner of the statue was an astronomer. The statue itself was decorated in the manner typical of this occupation, because Senty is depicted carrying a gnomon. ${ }^{132}$ Besides stating that he participated in the divine cult and had inherited the office from his father, Senty styles himself as one "who knows the hour correctly according to the will of the god" ( $r h$ wnw.t mtrib ntr). He is also "the one who proclaims ( $d d)$ the years (rnp.wt), months ( $3 b d . w)$ ), days (hrw.w), and hours (wnw.wt) as well as the course (sb) of the stars $\left(s b_{3} . w\right)$ by observing $\left(m_{33}\right)$ their way (w3.t)" ${ }^{133}$ Aside from boasting about participation in religious festivals, Senty was clearly interested in telling the world that he knew time management through observational practices, and this was stressed in both text and image. The reference to observing the motion of the stars does not necessarily imply planets, since it could refer to stellar constellations important for measuring time, such as the decans. At the minimum the statement can be taken to imply that Senty was familiar with the regularities of the heavens. Nothing in the inscription clearly discloses astrological activities. Yet, according to the ed.pr., he describes himself using the following phrase found in biographies and descriptions of sages such as Imhotep: "the one who announces what is coming (sr iy.t)" ${ }^{134}$ Throughout most of Egyptian history this phrase and its derivatives are, however, rarely associated with divination, but with the ability of officials to anticipate or announce matters related to their profession as a result of

130 Daressy 1919: 276-278. The statue is further discussed by Clagett 1995: 489-490; Birk 2014: 87. 131 It is unclear whether the title is to be read as wnwn.w, "stargazer" (Wb. I: 318.11; Clagett 1995: 490; Winkler 2016: 273, n. 93), a rarely attested title (but see von Lieven 2000b: 42; Peust 2014: 376; von Lieven 2020: 424), or as wnw.ty as suggested by Birk 2014: 87 following the ed.pr. (see Dhennin 2012: 77, n. 69; Altmann-Wendling 2018: 784, n. 23). The group can be discerned, though the reading of the signs before the seated man determinative is uncertain. The first $w n$ can be understood as a converter, "while I was an astronomer". For the period, however, one would expect imy-wnw.t rather than wnw.ty (see Birk 2014: 82).

132 See $n .126$ above.

133 Daressy 1919: 278; Altmann-Wendling and Stockhusen 2020: 111.

134 Cf. n. 107. Cannuyer 2010: 516, n. 1, refutes this reading but does not provide an alternative interpretation. The verb is oddly written. The ed.pr. renders it as $\underset{i}{\mathbf{I}}$. What appears to be an ideographic stroke is written under the first sign. 
their acquaintance with the teachings. ${ }^{135}$ Nevertheless, as divination and divinatory treatises began to be classified as such, ${ }^{136}$ one can assume that when the phrase was attributed to mortals, it could also be connected to divination, as was occasionally the case with deities and sages. ${ }^{137}$ Note, however, that the phrase on Senty's statue is not found directly adjacent to the description of his astral knowledge.

\subsection{Harentebo}

A longer text (Cairo JE 38545) belonged to a man called Harentebo (usually known as Harkhebis vel sim. in the scholarly literature), who was a dignitary in the Delta. ${ }^{138}$ The date of the statue is debated. It has been ascribed to the 30th Dynasty on stylistic grounds, while the early Ptolemaic period is also possible. Unlike Senty, he does not style himself as an astronomer by providing a title. Instead he describes the scope of the astral knowledge that he possessed. The relevant part of the inscription reads as follows: ${ }^{139}$

The prince, governor, and unique friend, who is educated in the sacred script ( $m d w-n t r)$, who has seen $\left(m_{33}\right)$ all that is visible on earth and in the sky, who is educated in observing ( $\left.m_{33}^{3}\right)$ the stars ( $\left.h_{3} b_{3} s . w\right)$, among which there is no erring, who announces ( $\left.s_{s} r\right)$ the rising ( $n h)$ and the setting $(h t p)$ in their time together with $(h n c)$ the gods that foretell (sr) the future ( $h n . t i)$, after he has purified himself for them in their days of coming forth, when the Effective One ( 3 h) was beside the Phoenix (bn.w) $)^{140}$ above them so that he is able to pacify them with his utterances $(t p-r(3) . w=f)$, the one who sees ( $\left.m_{33}\right)$ the rising $\left(t w_{3}\right)$ of every star in the sky, who knows the coming of ... (?) the great inundation and everything which will come into being in a perfect year ( $r n p . t$ nfr.t), the one who foretells ( $s r$ ) the coming forth $(\operatorname{pr}(. t))$ of Sothis in the beginning of the year, seeing $\left(m_{33}\right)$ her in her first feast, who

135 Cannuyer 2010: 284-543.

136 See n. 108 above. The hemerologies, for instance, can also be referred to as teachings (Leitz 1994: 428).

137 Ritner 1993: 36-37, n. 167. The epithets describe what in a wider sense can be regarded as oracular qualities of the deities when declaring the future. When attributed to humans it possible that it gradually became used in such a sense too.

138 For the latest treatment of this inscription, see Altmann-Wendling and Stockhusen 2020: 103-115; Gautschy 2020: 370.

139 The translation largely follows that of Altmann-Wendling and Stockhusen 2020: 104-106, who also provide a bibliography for the monument (see also Winkler 2016: 272-273, n. 93).

140 Phoenix could refer to the planet Venus (Neugebauer and Parker 1969: 180-181 and 214; Parker 1974: 52; Quack 2018a: 106-107; 2019) or in fact the Sun or the Moon can be implied by the two terms (Altmann-Wendling and Stockhusen 2020: 105). 
calculates (ip) her trajectory (nmt.t) to the times of touching the ground ( $d h n)^{141}$ (?), who observes all that she makes so that everything that she foretells (sr) is in his hand, the one who knows $(r h)$ the northern (hd(.t)) and southern (hnti) path of the sun disk, who announces (šsr) all its omens (bi3.w) and all their revelations ( $\operatorname{di}(. t)-r(3)=s n)$, which produce (di (.w)-hp $\langle r\rangle)^{142}$ that which he says-for they have come into being, arriving in their (right) time ( $n w=s n)$-, who arranges ( $\check{b} b \check{b} b)$ the hours in accordance with the two times (day and night) without confusion during the night in ...... every ... bringing (to the festival) at the beginning of every month, who knows ( $s w n)$ every visible ( $m_{33}$ ) thing in the sky since he has waited for it, who is skilled (in interpreting) their winds $(\underline{t} w w(. w))$ and their omens $(\check{s} m(. w)) \ldots$

After this, Harentebo seemingly switches topic and claims that he does not divulge anything that he has seen, except to the regent. Whether the claims relate to his astral activities or something else is not clear. The text then continues with an enumeration of his other sacerdotal duties. He was also a "scorpion charmer" (hrp-srq.t), a kind of physician, ${ }^{143}$ and he describes the responsibilities that came with that title. Quack has shown that this part of the inscription quotes the chapter treating the role of this priest in the so-called Book of the Temple. ${ }^{144}$ It is possible that the astronomical part could also be quoting from that work, at least partially, but the relevant section is not preserved.

The inscription informs us that its owner was a highly educated priest, one that had gone through the higher echelons of the sacerdotal education. But what does the inscription say about the astronomical knowledge of Harentebo?

The first statement that potentially can be attributed to some form of knowledge pertaining to the sky, "who has seen all that is visible on earth and in the sky", appears to be a boilerplate expression. It is also found in the so-called Book of the Temple where the duties of the Priest of Sachmet ( $w b$ Shm.t) are treated. ${ }^{145}$ It is, therefore, unclear whether anything particular is implied due to the seemingly general nature of the statement and its use in other contexts. ${ }^{146}$

The second assertion referring to astral knowledge poses a problem since it can be interpreted in two ways. The stars (his 3 s.w) themselves may be the ones

141 Altmann-Wendling and Stockhusen 2020: 105 leave the phrase untranslated but suggest the translation in a footnote.

142 Copt. хпо (Derchain 1989: 78).

143 Von Känel 1984: 201-203; Quack 2018a: 106. See also the chapters of Clancier and AgutLabordère and of Quack in this volume.

144 See Quack in this volume.

145 See Quack in this volume.

146 It has been suggested that the divinatory text known as the New Kingdom Menologion (Vernus 1981: 89-124, esp. 101-104), which is explicitly directed to a $w c b$-priest, was used by the Priest of Sachmet (von Känel 1984: 239-240). 
"without erring", and are thus to be understood as fixed stars, ${ }^{147}$ which do not visibly change their position relative to one another. An alternative interpretation is that the phrase relates to the owner of the inscription: he is an unerring stargazer. The phrase thus becomes one of a more general nature. ${ }^{148}$ The first interpretation makes sense in the light of what is reported by Clement of Alexandria; the first Hermetic book that the temple astronomer was supposed to be acquainted with concerned precisely this phenomenon (see above).

Harentebo then goes on to state that he announces the rising and setting together with the "gods that foretell the future". ${ }^{149}$ The rising and setting probably refer to the fixed stars, but may also signify the decans. Since their course across the heavenly vault was important for chronometry, it is possible that this is what is implied. One can assume that the astronomer speaks about other stars than those referred to as rising ( $\left.t w_{3}\right)$ further on in the text. ${ }^{150}$ The second statement has been interpreted as referring to either the planets ${ }^{151}$ or the decans; ${ }^{152}$ both can be designated as gods and both were used for making astrological predictions. ${ }^{153}$ Considering how indistinct the phrasing is, it is even conceivable that Harentebo includes both categories of celestial bodies in his statement. However, they constitute another entity than the ones implied by the rising and setting due to the presence of the connective conjunction hanc.

The passage could of course pertain to astrology-it is impossible to know for certain. If it is taken to refer to the decans, it is possible that Harentebo, instead of talking about proper astrology, alludes to the effect of these entities as described on the so-called Naos of the Decades. ${ }^{154}$ Rather than providing prognostications depending on various configurations of planets and constellations, the text describes how the decans affect life on earth by appearing in the sky.

It is difficult to interpret the details of the passages concerning the astrologer purifying himself, the "Effective One" being besides the "Phoenix", and the pacification of these entities with his utterances. It is unclear whether the

147 Neugebauer and Parker 1969: 214; Dieleman 2003: 285; Altmann-Wendling and Stockhusen 2020: 109. See n. 107 above for the term hisbs.w.

148 Derchain 1989: 76; Quack 2018a: 106.

149 Cannuyer 2010: 514-518.

150 One suspects that this is a stock phrase without any particular reference. It merely signifies that Harentebo is aware of every star found in the sky.

151 Dieleman 2003: 285, n. 55.

152 Altmann-Wendling and Stockhusen 2020: 104.

153 E.g. Quack 2019.

154 von Bomhard 2008. See also Leitz 1995: 6-38; Quack 2010: 175-181. 
inscription is dealing with the Sun and the Moon or Venus and a decan. ${ }^{155}$ What is described may relate to such ideas as found on the above-mentioned naos, particularly as the decans were held responsible for terrestrial events, including the Nile flood and various calamities. ${ }^{156}$

The inundation is the next topic mentioned by the inscription. In the Egyptian calendar, its date gradually changes, and Harentebo indicates that he is able to make adjustments to arrive at the correct day for this event. Consequently, the next topic refers to the appearance of Sothis, whose heliacal rising ideally occurred at the beginning of the inundation. The inscription states that Harentebo is able to predict the date and follow the star through its visibility in the sky before it disappears at the western horizon. Though the star has a regular movement across the sky, the astronomer claims to be able to calculate (ip) its course-just as Thoth or Imhotep. ${ }^{157}$ That is not all that Harentebo does, however, since he declares that he has command over what Sothis foretells. This seems to be a reference to celestial divination involving the stars. ${ }^{158}$ The practice may have entailed computing zodiacal positions of the planets, as is attested in several papyri. Simpler methods could also be involved, such as considering the colour of the star in conjunction with weather phenomena. ${ }^{159}$ Yet, a more conservative interpretation would be that he is not really referring to divinatory practices but to natural events and feasts

155 See n. 140 above. Parker 1974: 52 suggested that if the text indeed refers to Venus (bn.w), the stargazer possibly alludes to divinatory techniques based on Venus phenomena similar to those known from Mesopotamia. Quack 2018a: 107 rejects such a view. In this connection, note that there are records detailing the motion of Venus that spanned as much as a century (Ryholt 2018: 144), but for now one can only speculate about a connection. Quack 2019 also mentions a procedure text involving Venus from the same locality.

156 von Bomhard 2008. The purification surely refers to some kind of religious act. A speculative suggestion would be that the stargazer took part in a cultic action to make sure that the decans produced beneficial outcomes rather than negative ones. Yet it is perhaps more prudent to understand the phrase as referring to some kind of ritual cleansing that was supposed to take place before entering service as a stargazer. References to ritual cleansing are found in divinatory contexts. As an example one can mention a lecanomantic text of the New Kingdom, P.Turin 54065 (Demichelis 2002: 154), where the practitioner is referred to as a "sage" (rh-ih.t). The same can be found in numerous instances in P.Mag. in connection to performing divinatory rituals.

157 See $n .107$ above.

158 So already Neugebauer and Parker 1969: 213; Derchain 1989: 86-87. See also Quack 2017b: 191-192.

159 Note that P.Cair. II 31222 (see $\mathrm{n} .18$ above) possibly mentions winds in connection with the appearance of Sothis. Yet it cannot be excluded that the sign in question in fact represents the name of the planet Jupiter, which could be written in the same way (e.g. Neugebauer 1943: pl. 4; Dieleman 2005: 159, n. 35), although there is no clear star determinative visible on the published photograph. 
following the rising of the star. Similar considerations can be made regarding Ankhhor's statement about Sothis.

Next Harentebo turns to his knowledge of the Sun's southern and northern voyages. The phrase clearly refers to the winter and summer solstices. ${ }^{160}$ That is, he is able to predict these dates and from when the days become shorter or longer. But his knowledge of the Sun also stretches into the realm of divination, as indicated by the statement that he announces all the omens of the Sun. The word translated as "omens" is bi’.w, which literally means "wonders", if it is not just a variant plural spelling of bis.t, "amazement" or "confusion", which can be written in the same way. ${ }^{161}$ The same root also designates "oracle". The "omens" announced by Harentebo can be defined more precisely. It is likely that the statement refers to the ability to predict solar eclipses. Such a conclusion is not only to be drawn from the fact that solar eclipses are the most prominent omens related to the Sun, with a reasonably long history in Egypt, ${ }^{162}$ but also because of a proximity between the term used by Harentebo and bis.t. The Coptic derivative of the latter word is евн, which compounded with eıpe means "darkness" and is used to describe eclipses just as its Demotic forerunner ${ }_{3}^{3} b_{3} . t$ (vel sim.). ${ }^{163}$ The fact that ir is lacking is of secondary importance. The term appears as iby.t in the "Book of the Temple". ${ }^{164}$ To be able to announce eclipses implies that Harentebo, at least in theory, could

160 E.g. Derchain 1989: 78; Altmann 2010: 101-103; Altmann-Wendling and Stockhusen 2020: 109.

161 E.g. Wb. I: 440.3; Wilson 1997: 308. See also Graefe 1971: 113-139.

162 See n. 86 above for the so-called Vienna Papyrus on Eclipses and Lunar Omens. Already during the Third Intermediate Period eclipses were recorded as portents, e.g. in the "Chronicle of Prince Osorkon" (Jansen-Winkeln 2007: 186-196; Ritner 2009: 362-363). Summaries of the discussions surrounding this document are provided by von Lieven 1999: 103, n. 157; Krauss 2007: 211-223; Thijs 2010: 181-182. Other eclipses in Egyptian literary and religious texts are discussed by e.g. Smith 1991: 105-108; Ryholt 2011: 63 (P.Berlin 13588); Altmann 2010: 91-97 (Urk. VI). P. Carlsberg XI 5 contains an episode which probably refers to such practices. It mentions the observation of the "disc" (itm) for divinatory purposes, but the stargazers notice that Orion, lit. "Star of Osiris" (syw $n$ Wsir), was displaced from its path ( $w h_{3}=f r$ t $3 y=f$ mi.t).

163 E.g. Vycichl 1984: 38. Although there have been different interpretations of the etymology (Smith and Tait 1984: 45; Quack 2002b: 168), the fact that $b b_{3} . t$ is often written with an initial $i$ in the Graeco-Roman period (Graefe 1971: 149) further enhances the standard interpretation. A speculative suggestion would be that the meaning of $3 b_{3} . t$ and евн is derived from the fact that the word was applied to omens of the Sun and the Moon, i.e. primary eclipses, and therefore took over this meaning in the popular language. Note that what is interpreted as the same word with an abstract prefix added метевн still means "amazement" in the Bohairic dialect, which also can render the word as $2 є$ вı. The addition of 2 can perhaps be compared to гтоо $\epsilon$, which etymologically comes from $h_{3} . w d w_{3} . w^{*}$, "time of morning" (Vycichl 1984: 317). That is, h3.w bi3.t* would literally be translated as "time of amazement/confusion".

164 Quack 2002b: 168. 
calculate when they occurred. It is conceivable that such methods had reached Egypt from Mesopotamia; Babylonian astronomers were able to predict eclipses with some success ${ }^{165}$ and a top-of-the-line astronomer, such as Harentebo, would surely be acquainted with them. Note that this is precisely what some astronomers a few centuries later claim to be able to do (see below). The prediction of lunar eclipses is also known from at least the first century BC. The statement that follows also seems to hint at precisely this. Besides disclosing that he is able to reveal the prognostications based on eclipses-perhaps to the court: his relation to the king (nb t3.wy) is thematised later on in the inscription ${ }^{166}$-he stresses that they occurred in due time (hpr.n=sn iy $r$ nw=sn), which probably means just as he had predicted. Although not a direct textual parallel, the text on the statue may give an insight into what was implied by the passage referring to eclipses found in the so-called Book of the Temple.

Thereafter Harentebo returns to more ordinary matters, stating that he is able to divide the hours properly. By this he probably insinuates that he is able to use a gnomon, a clepsydra, and a sundial ${ }^{167}$ as well as being acquainted with texts that explain the length of the hours of day and night throughout the seasons. By referencing the beginning of the month, Harentebo boasts that he is able to determine the first crescent, which defines the beginning of the lunar month. This date was important for establishing priestly services and festivals celebrated in relation to the Moon; and here the astronomer may be mentioning leap days. ${ }^{168}$

The section of the text that treats Harentebo's astral knowledge is concluded by a statement about his general experience: "Who knows every visible thing in the sky since he has waited for it", that is, spent time observing or learning about the phenomena. The fact that the stargazer stresses both observational and predictive practices in relation to the celestial bodies throughout the inscription confirms this conclusion.

The final statement refers to divination; he claims to be skilled in (interpreting) the winds and omens (of the sky). ${ }^{169}$ Here Harentebo proclaims that he was engaged in techniques of celestial divination that have been known in Egypt at least since the New Kingdom, and were conducted by a sort of mantic specialist. ${ }^{170}$ These techniques were probably based on the Mesopotamian celestial divination

165 E.g. Steele 2000: 421-454.

166 Derchain 1989: 79-80; Clagett 1995: 492.

167 See n. 98 above.

168 See Altmann-Wendling 2018: 114-116 and 786; Altmann-Wendling and Stockhusen 2020: 109.

169 The reading was originally proposed by Ritner 1993: 36-37, n. 167.

170 See n. 116 above. 
series Enuma Anu Enlil or a prototype thereof. ${ }^{171}$ Such texts are attested in Egypt from the New Kingdom until the Graeco-Roman period in Egypt. ${ }^{172}$ At the time Harentebo lived, such techniques would have been far from novel in Egypt.

The inscription is a key piece of evidence for understanding the role of Egyptian astronomers in the period under discussion. In addition to being able to determine and divide the various chronological cycles, such as hours, days, seasons, and years, operating with longer and seemingly more irregular temporal patterns was also part of their repertoire of skills. Their ability to predict solar eclipses implies that they were able to predict lunar eclipses with some success, using a similar technique as presented by P.Berlin 13146-7. Though it is not explicitly stated, one must imagine that being able to calculate the periodic motion through the zodiac of the planets and their synodic periods was part of the repertoire. An astronomer was thus sufficiently equipped to cast even more advanced horoscopes for natal astrology. Yet there is no evidence that Harentebo participated in such an activity. On the other hand, as has already been pointed out by several commentators, there is plenty to show that he was engaging in various forms of celestial divination, from eclipse omens to brontoscopic predictions and perhaps Sothis omens. ${ }^{173}$ The statue reminds us that the astronomers possessed a broad repertoire of knowledge and that they sometimes served as diviners, as is known for other types of priests.

\subsection{A Family of Practitioners}

In Roman-period Dakke and Philae, a few inscriptions preserve relevant information about the astral knowledge of priests. In particular, Graf.Dak. 30 (3rd cent. AD), Graf.Phil. 410 (3rd cent. AD) ${ }^{174}$ and 421 (AD227/228) are relevant. ${ }^{175}$ These inscriptions commemorate the presence of Nubian priests participating in rituals at the sites. They were commissioned by members of the same family, several of whom engaged with astral knowledge. The beginning of the first inscription is written with hieroglyphs, while the second part uses Demotic. The other two make

171 See e.g. Koch 2015: 163-182.

172 Parker 1959; Roccati 1984: 249-253; Collombert 2014: 15-26. See also Quack 2017b: 189-206.

173 The statements about the "gods that foretell the future" and "what Sothis foretells" can viably go beyond mere stock phrases (see nn. 135 and 137 above) in Harentebo's case, particularly since he explicitly refers to other divinatory techniques.

174 The suggested date is probable, but the inscriptions remain largely undated.

175 Astronomers (imy-wnw.t or similar) connected to the cult of Isis are found in Graf.Phil. 60, 61, and 65 (Quack 2018b: 120). 
use of Demotic and a few Hieratic insertions, particularly in the latter text. This use of mixed scripts indicates a higher level of learning, as is fitting for men with elevated sacerdotal positions. ${ }^{176}$

The graffito of Harenyotef, son of Wyekye (Graf.Dak. 30), ${ }^{177}$ refers to him as a man of many sacerdotal titles. Alongside several that connect him to Isis and Thoth, he is also royal chief ritualist (hry-tp) in Kush and great sage (rh-ih.t wr), which presents him as an equal of the legendary Imhotep. ${ }^{178}$ The titles that directly pertain to things celestial are: prophet of Sothis (hm-ntr Spd.t), overseer of the motion of the Moon (imy-r(3) $\left.m \check{s}^{\ulcorner} n I^{\prime} h\right),{ }^{179}$ priest of the five planets $\left(p(3) w^{c} b n\right.$ p; $5 b_{3}(. w)$ nh.w), and "one who knows the time(s) of solar and lunar eclipses" (nty

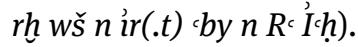

The same person is also attested in Graf.Phil. 410 together with his brother and bearing similar titles as in the aforementioned inscription. Those pertaining to astral knowledge are styled slightly differently, however. The brothers refer to themselves as "(Those) who know the appearance of the five planets" (nty rh n’ $\check{s}^{\varsigma} . w$

176 Moje 2014: 126-127.

177 The name of the father means "star" (Pope 2008/2009: 89-90; Rilly and de Voogt 2012: 213). Although it is tempting to see connection between onomastics and profession, it is probably a coincidence.

178 The title is to be read as "great sage in the towns of the Great Green" ( $r$ h-ih.t wr m niw.wt n $W_{3} \underline{d}$-wr). It can be compared to an inscription from Debod mentioning the legendary sage Imhotep (Wildung 1977: 174), who is called "chief scribe of Upper and Lower Egypt" and "great sage in the whole land" ( $r$ h-ih.t wr $m$ ts $r$ - $\underline{d} r=f)$. See Coulon 2006: 20 for similar titles. Depauw 2001: 2, n. 7, considers the title of the Nubian dignitary to have astronomical connotations. That $r h$-ih.t was connected to astrology as a form of divination can perhaps be seen in the Coptic word $\left.\lambda_{1(1)}\right)_{\gamma}$, "astrologers", which may come from said term or rh.w, "knowers" (Černý 1976: 21).

179 von Lieven 2020: 411, n. 1 . There are other readings of the title. The first sign, which is read as imy-r(3) has been understood as the preposition $m$ in the ed.pr. and is followed by e.g. Pope 2008/ 2009: 89; Moje 2014: 125-126; Nagel 2019: 679; Ashby 2020: 158. Török 2009: 459-461; and Quack 2018b: 121 suggest $i m y-r(3)$ for the first sign but understand $m \check{s}^{\varsigma}$ as "army", "crowd”, or "troop", i.e. the title $i m y-r(3) m \check{s}^{\varsigma}$, "general", instead of "voyage", "step", or "regulation" (vel sim.) of the ed.pr. This reading would point to a cultic association of the Moon and suggest that the titles refer to religious roles of the celestial bodies rather than proper astronomical knowledge (though the latter is of course not excluded by the former). This interpretation is followed by e.g. Altmann-Wendling and Stockhusen 2020: 111-112. von Lieven's suggestion is supported by the fact the word in question is written with the walking legs determinative. The verb $m \check{s}$ c is connected to the Moon in the Vienna Eclipse Papyrus (col. iv 7) and to planets in, for example, OMM 65 (Menchetti 2009: 232-233) as well as the so-called procedure texts relating to Mercury (Ossendrijver and Winkler 2018: 393). $M \check{s}^{\circ}$ is also attested in connection to stars in the so-called Book of Nut (von Lieven 2007: 359). The Demotic expression $n_{3}$ mšc.w $n$ t3 $p . t$ in the Canopus Decree, given

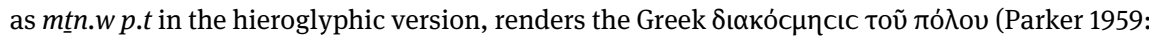
20). 
$n$ p; 5 sw.w nh.w) and "find the time of solar and lunar eclipses" (gm wš $n$ ir 3 s $n$ p

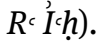

Wyekye, son of Harenyotef, who is commemorated in Graf.Phil. 421, was probably the father of the two above mentioned stargazers. He enumerates fewer titles but was also linked to Isis, and he held the position of royal chief ritualist of Kush. His connection to the stars is limited to being a prophet of Sothis, overseer of the motion of the Moon, and priest of the five planets.

From the titles in Graf.Dak. 30 and Graf.Phil. 421 one gets the impression that there was a stellar cult connected to Sothis, the Moon, and the five planets. It is more probable, however, that the sacerdotal titles were a way of conveying areas of astral knowledge. They were merely a cultic paraphrasis. The actual phenomena are, however, described with the same terminology as found in astronomical texts. This is at least suggested by the inscription in Graf.Phil. 410. Instead of being the "priests of the five planets", Harenyotef and his brother are described as the "ones who know the rising (times) of the planets". That can be assumed to include the knowledge of their periodic planetary motion through the zodiac, synodic periods, and other phenomena. Considering that the rising of the planets is specified in relation to the zodiac, ${ }^{180}$ it is not unlikely that they were able to cast horoscopes with this knowledge. ${ }^{181}$ In general, it is probable that the individuals in question possessed much of the same knowledge as described by Harentebo. That Harenyotef and Wyekye were prophets of Sothis could imply that they were able to "calculate" its path in a similar way as the astronomer from the Delta, rather than this being a reference to a cult of Isis-Sothis. ${ }^{182}$ Whether they engaged in divinatory practices related to Sirius is not certain, but the title prophet could certainly imply something in that vein, ${ }^{183}$ particularly since they appear to be connected to a royal court. Considering the Zeitgeist of the 3rd century AD, it would be unusual if they were not familiar with such techniques. The title "overseer of the motion of the Moon" suggests that they were able to predict its motion, perhaps also to predict the first crescent and knowledge of its 25 -year synodic period. Finally, the ability to calculate eclipses signals a high level of astronomical knowledge that surely subsumed other tasks, such as being able to establish the season, the length of the

180 E.g. Ossendrijver and Winkler 2018: 391.

181 The existence of a faïence zodiac dish, UC 43929 (Lacovara 2005: 110), dated to the GraecoRoman period from Meroë underlines familiarity with such techniques and the impact of astrology in the region. It is possible that this is a fragment of a pinax (see $\mathrm{n}$. 31 above). Only the depictions of Capricorn (goat-headed fish) and Aquarius (child holding an eel) are preserved. These two signs were misinterpreted in the publication as Pisces and Aries.

182 Török 2009: 459-460.

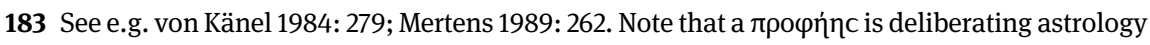
with Plato in the Greek P.Ryl. II 63. 
hours, the solstices, etc. Due to the ominous nature of eclipses, one can be fairly certain that a scholar capable of predicting them would also engage in eclipse divination.

The celestial phenomena mentioned in the inscriptions at Dakke and Philae predominantly point to predictive astronomy rather than observational practices. Since the priests refer to the rising times of planets and the timing of eclipses, their astronomical engagement reached beyond mere timekeeping. As seen above, Harentebo engaged with both predictive and observational practices. The latter cannot have been unfamiliar to the Nubian stargazers either. As astronomers, their duties would by and large include tasks similar to those of their colleagues further up the Nile. That is, to observe the celestial bodies, perhaps from an observatory such as the one at Meroë. ${ }^{184}$ The way they expressed their astral knowledge departs from earlier inscriptions by more strongly highlighting phenomena relevant to astrology. This might reflect the spirit of the time. In the wake of the "zodiacal and mathematical turns" in the astral sciences, astrology and eclipse predictions gained the same prominence as determining time and annual celestial events in earlier periods.

\subsection{Characterising the Stellar Scientists}

The inscriptions show that the astronomers particularly highlight their ability to measure or announce time and predict phenomena of the major celestial bodies, thus foregrounding their knowledge of the constitution of the skies, while their ability to forecast the future was less frequently stressed. The ability to "announce time" may, on the other hand, not be as plainly defined an activity as it first appears: the process of constructing a horoscope could be referred to as "calling/ reading the hour" (‘š-wnw.t). ${ }^{185}$ Much of the technical knowledge of the astronomer is in line with the requirements for performing celestial divination or making

184 See $n .98$ above. Since the capability to establish times was crucial for correctly performed rites, and depictions of zodiacs in temples have been connected to rituals (see n. 5 above), Ashby 2020: 155-158 suggests that the epithets were mentioned with particular reference to cultic activities in which the priests participated at Philae. Their competence to perform such tasks is apparent from the inscriptions, but it is too narrow an appreciation of the passages.

185 Menchetti 2009: 231 points to the pinax in P.Mag. iv 21, which is called pyngsn 'š $n$ wnw.t, and that the process of laying out the stars for an astrological consultation in the ostracon OMM 782 is referred to by the same term, albeit partially reconstructed. The expression is certainly partially related to the

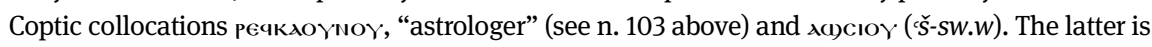
to be understood as a synonym to the previous expression but was earlier used as a technical term pertaining to astronomy. 
astrological predictions. The fact that rising times or eclipses are calculatedphenomena that did not have any direct practical purpose for timekeeping-invites such a conclusion. As already stated, one can assume that the astronomers discussed above participated in divinatory activities, even if these were not directly, or separately, emphasised in their autobiographies or commemorative inscriptions.

The preserved inscriptions belonged to individuals from the higher echelons of the priestly hierarchy, but evidence suggests that astronomers were not necessarily always high-ranking priests. Astral knowledge or astronomical duties are also attested among temple servants belonging to the lower sacerdotal ranks. ${ }^{186}$ At the same time, only infrequently do the texts detailing specific areas of astral knowledge attribute the title of astronomer to the commissioners of the inscriptions.

One can compare the situation with the so-called Israel stela, which mentions the stargazers without providing them with titles known elsewhere but with epithets describing their knowledge. A passage from the mythological narrative of P.Carlsberg XI 5 also fits this pattern. The passage describes how certain stars are displaced as an ominous sign. Thereupon one of the main protagonists orders sages to be brought. The text seems to imply that these men had a connection with Mesopotamia, but due to the fragmentary nature of the manuscript the specifics are unclear. They are instructed to scrutinise (gšp) the sky and observe ( $n w$ ) the disk in order to interpret the signs. Following the orders, they read their books in order to unravel the situation. The interpreters of the sky are, as far as can be seen from the incompletely preserved fragment, not referred to as astronomers, but as wise men.

\section{Astronomers and Astrologers at Tebtunis}

Evidence for astral knowledge at Tebtunis can be found in multiple texts of various sorts from the site. ${ }^{187}$ Though many of these are difficult to date beyond the first or second century AD, several documents suggest that a number of people with connections to the local temple had access to such knowledge.

186 Winkler 2016: 273-274. Perhaps needless to say, the calendrical reforms introduced by Ptolemy III Euergetes mentioned on the Canopus Decree point to a widespread basic understanding of the relations between astronomical events and timekeeping. Cf. also P.Insinger xxxii 5: "He created the constellations, which are in the sky, so that those who are on earth know them"

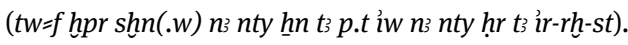

187 Winkler 2009: 361-375. 
Several indications that this was the case already in the Ptolemaic period are found in documentary texts. At the end of the second century BC, the temple notary Haryothes, son of Harmysis, ${ }^{188}$ is attested in a number of papyrus deeds that he drew up for the inhabitants of the village: e.g. GEM 66581 (134 BC); P.Cair. II 30628 (119 BC); P.Köln.Dem. 2 (BC 110). A few years into his career, he must have acquired the office of temple astronomer. In at least three texts (P.Cair. II 30607-30609) from period BC 128-124, he signs the documents that he drew up using the title "temple astronomer of Tebtunis” (imy-wnw.t (n) t3 ḥw.t-ntr (n) T3-nb-tz-tny). This suggests that he signed them while also possessing this role in the temple. Since priestly offices could be bartered, it is plausible that he acquired the office of temple astronomer a few years into his tenure as a temple scribe, which would explain why he did not use the title in the first deed in which he is attested (GEM 66581). For unknown reasons, he may subsequently have sold the office. He did not use the title while signing the later documents, such as P.Köln.Dem. 2. This reveals that more than one person among the priests was able to conduct the duties connected with the office (assuming that the person who possessed the title also fulfilled the responsibilities that came with it).

In the Roman period, there are indications among the documentary papyri that the same situation persisted. That is, more than one person was able to carry out the tasks of the astronomer. The Greek P.Tebt. II 599 (2nd cent. AD) contains an offer for the purchase of the office of the prophet in the temple. As part of the offer, the person also promises to carry out other priestly duties, among which those of the astronomer. ${ }^{189}$ Lists of priestly expenses from the temple (e.g. $S B$ XVIII 13118), however, suggest that there was only one remunerated office holder at one time.

The number of such officials probably depended, at least in part, on the size and economic strength of the institution in question. The above mentioned statues of astronomers from Ptolemaic Thebes show that there were multiple priests with such duties in the temples there, and inscriptions from Dendara and Edfu also mention a plurality of astronomers. ${ }^{190}$ The same can be understood from Graf.Phil.

188 Winkler 2016: 273, n. 94.

189 In a few papyri, primarily from second-century AD Tebtunis (P.Lund III 9; P.Tebt. II 294, 295, and 599), the sacerdotal duty of the $\beta \alpha \iota \varphi$ เо $\alpha$, which implies the carrying of a palm staff or branch, is attested. Although it is not entirely clear what the office implies (Perpillou-Thomas 1993: 188-189), it has been suggested that it is connected to temple astronomers (Pfeiffer 2018: 683, n. 56), since the latter carried such an implement (see n. 104 above). Nevertheless, the suggestion is complicated by the fact that the office of the $\dot{\omega} \rho \lambda_{\lambda o ́}$ oc is mentioned separately from the $\beta \alpha \iota \varphi$ เорí in P.Tebt. II 599. If the latter is connected to astronomy, perhaps the two titles indicate various ranks or different duties of the same trade.

190 Derchain-Urtel 1989: 178-180. 
421, where two brothers announce their acquaintance with the stellar arts. The depictions of astronomers at work also involve two individuals taking part in the observation of movements in the sky. ${ }^{191}$ Even if scholarship generally assumes that two astronomers observed the night sky in order to measure time, and perhaps a pair for each phyle, R. Birk has recently convincingly argued that astronomers could carry out this task alone with the "astronomical trident". ${ }^{192}$

Unfortunately, no hitherto published document from Tebtunis shows that the astronomers were also engaged as astrologers, though it is beyond doubt that they were able to do so, having the expected standard skillset that came with their office. Priests who pursue astrological activities are attested already for the Ptolemaic period. In addition to astrological manuals, texts connecting entire biographies to zodiac signs have been found at the site along with astronomical papyri from the same period. ${ }^{193}$

There is other evidence for particular astrologers in Tebtunis. As has been noted, Panesis, son of Pakebkis, a priest of the Soknebtunis sanctuary during the second half of the second century $\mathrm{AD}$, was probably the individual who wrote the astrological text(s) of P.CtYBR 1132 and P.Carlsberg 420. ${ }^{194}$ According to Ryholt, he composed the latter astrological manual by means of collation. The fragmentary colophon is restored as follows: "This is its very end, it being written (i.e. copied) and it being corrected in accordance with that which was written before

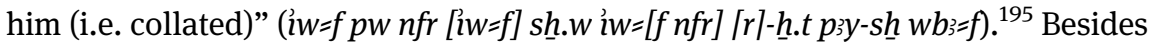
copying literary texts (e.g. P.Tebt.Tait. 15), ${ }^{196}$ it is fairly certain that Panesis was able to use Greek astronomical tools; he clearly was able to read and write Greek, even if at a low level, as is shown by PSI X 1143 (AD 164), a Greek document that he himself signed.

It is not known if he was indeed engaged as a temple astronomer. No documents indicating this survive, but we know that he was styled as icpeúc in Greek documents. This title is rather generic, but in a Demotic document,

191 See Fig. 1 in Depuydt 1998b: 173. See n. 189 above, however.

192 Birk forthcoming.

193 Ryholt 2018: 143-144 understands the texts as collections for the study of astrology, perhaps recordings of actual lives used to construct astrological handbooks; several of the events that occurred for the mentioned individuals are paralleled among the predictions of the Demotic astrological manuals. A reversed process is also conceivable, however.

194 Winkler 2016: 275-277. See Ryholt 2017: 177-182; 2019: 506-507 for other scribes attached to the Tebtunis sanctuary.

195 Ryholt 2017: 174.

196 Winkler 2016:277, n. 111. His taste for scholarly activities is perhaps also shown by the fact that the letter P.Cair. II 31220, which Panesis wrote, is addressed to a prophet (hm-ntrir), who is also called a sage (rh-ih.t). 
P.Tebt.Tait. 22, his priestly position is specified as m-ntry. From what can be gathered, this title seems to be specific to the Soknebtunis sanctuary, but it is questionable whether it signifies an elevated rank. ${ }^{197}$

What, if anything, is known about the scribe who penned the astrological manual of P.Carlsberg 81? He wrote the text was likely active during the second century $\mathrm{AD}$, as suggested by the palaeography of the text. Unfortunately, no name or title has survived that can be attached to a specific individual. It is fairly certain that the same scribe penned at least one so-called Sothis text, P.Cair. II 31222, a text relating to universal omens. ${ }^{198}$ That one and the same priest, viz. astrologer, engaged in both kinds of astrology should be no surprise. Practitioners of this art who wrote in Greek could often treat both kinds of phenomena. If Jones's understanding and dating of the Cairo text is correct, ${ }^{199}$ the astrologer can be placed in the mid-second century AD-Jones dates it to AD 134-and we can postulate that this man still engaged in casting the fortune of the coming year. It also suggests that Sothis texts were kept for "practical reasons" by the priests rather than being merely theoretical exercises from a bygone time or something only used by astrologers directly connected to the royal house.

There are other individuals-unfortunately remaining nameless to us-who were engaged in several areas of knowledge in addition to the astral arts. One

197 Quack 2013: 111-116. The so-called Book of Fayum suggests that the title was the local designation of the $w^{c} b$-priest.

198 See $n .18$ above.

199 The preserved part of the text begins with a heading introducing the "Influences of Sothis" ( $n$ s shny $n$ Spd.t), upon which the forecasts begin with the position of the Moon in Sagittarius. These are followed by the prognostications of the five proper planets in their correct "Chaldean order". Saturn and Jupiter are found in the same zodiac sign. The remaining three planets (Mars, Venus, and Mercury) are said to be in Gemini, though the entry of Venus is not preserved. Hughes 1951: 256; and Quack 2017b: 201 reconstruct the last poorly preserved lines as an entry relating to the Sun in Sagittarius, following the explanation given by Hughes 1951: 256-257. Instead of organising the entries by planet in various zodiac signs according to their order, as the Sothis text in PSI inv. D 39 does (at least for the superior planets), he suggested that the text, or at least the preserved part, operates on a principle of "conjunction" and "opposition". First it began with the three first mentioned celestial bodies being in the sign opposite the rising planet, while the other celestial bodies were in the same one. The reconstructed section beginning with the Sun would take the reverse approach, i.e. the rising was to be observed in the evening. It is possible, however, that the Cairo text in fact is not a manual per se, but an extract from a "Sothis Text". Jones 1998: 131 suggests that the configurations displayed reflect a proper calculation for a particular year, which in that case would be $\mathrm{AD}$ 134. The only planet that appears to be miscalculated is Mercury, which is also one of the more difficult to accurately place. In the papyrus, it has a longitude in Gemini according to Hughes, while it in fact would be in Leo. 
person, whose handwriting resembles the style of the scribes at Narmouthis, wrote P.Carlsberg $66,{ }^{200}$ a treatise concerning natal astrology based on the decans, and a narrative text. ${ }^{201}$ Another, who is commonly referred to as the "Nun-Hand", wrote at least one astrological manual relating to universal forecasts (P.Carlsberg 688), but also "historical narratives, a mythological narrative, a cult-geographic manual, a cosmology, a religious hymn or manual" and finally also "a dream book, and a prophecy". ${ }^{202}$ Yet another person who wrote a treatise relating to decans and prognostications made for women (PSI inv. D 35) also penned a number of narrative texts. ${ }^{203}$ The combination of, for instance, dream interpretation and astrology was also by no means alien to the Graeco-Roman astrologers, who were, inter alia, medics, pharmacologists, magicians, and engaged in other types of divination. ${ }^{204}$ Other Egyptian sources, such as the autobiography of Harentebo, also inform us that some Egyptian priests were specialists in various areas beyond astrology. The above-mentioned inscriptions at Dakke and Philae suggest something similar.

Papyri from other localities point to the same phenomenon, even if one cannot always connect the texts directly to a temple environment. While the corpus of the Graeco-Egyptian magical papyri contains ample references to astrological practices, one papyrus in the group stands out: PGM LXII (3rd cent. AD). It contains a number of horoscopes as well as magical texts. P.Oxy. XLVI 3298 is a notebook of a practitioner active during the third century $\mathrm{AD}$. In addition to containing an elaborate horoscope-the longitudes of the planets in the zodiac signs are given-and a simple one, it includes a brief note with instructions on how to perform a dream oracle. ${ }^{205}$ This again shows that astrologers were not limited to one craft within the divinatory trade but engaged in a wider array of techniques that a customer might wish to consult.

One might, of course, object that those who produced the mentioned Demotic manuscripts were just professional scribes who compiled them for others. But the evidence suggests that such texts often were copied by the very same person who

200 Chauveau 1992: 101-105.

201 Ryholt 2017: 181.

202 Ryholt 2017: 181-182. See also Quack 2014a: 122.

203 Ryholt 2017: 181.

204 See e.g. Gury 1996: 243-245. A different view is adopted by Heilen 2020a: 431, who claims that the two trades, astrologers and magicians, were mostly separate. He bases his argument on what he sees as a relative paucity of interconnected materials. They are also treated as such by Rives 2011: 679-692. For the dream interpreters in Egyptian sanctuaries, see Renberg 2016: 717-734.

205 The text is republished as Suppl.Mag. II 85. 
used them later on in one capacity or another. ${ }^{206}$ The divinatory texts, furthermore, do not seem to be part of the "theological holdings" of a temple. One can, therefore, assume that the manuscripts were kept as personal copies, potentially stored in a collective archive or library. The discussion above shows that the priests who wrote the astrological manuals were not only ritualists in the service of the crocodile god Soknebtunis; some of them were also "scientific polymaths". In other words, the priesthood, which included several astrologers, was interested in all areas of scholarly knowledge.

As a final remark, it can be added that even if one cannot precisely date all of the astrologers at Tebtunis, the quantity of individual hands attested in the various astrological and astronomical texts suggests that several practitioners of this art were active in the temple at the same time. As a consequence, the potential client of an astrological consultation could choose from multiple "dealers of fortune". Regrettably, the material does not reveal much about how the astrologers divided the market among themselves. Yet a few horoscopes from other localities suggest that clients who had their nativity cast and were dissatisfied with the consultation could have another one made for them. ${ }^{207}$

\section{A Few More Astrologers and Their Horoscopes}

Tebtunis is not the only site from which there is evidence for astrologers. Aside from the above-mentioned inscriptions a small assemblage of horoscopic ostraca from Athribis in Upper Egypt provides further information about astrologers in the Graeco-Roman period. At least seven such texts are currently kept by the Ashmolean Museum in Oxford. ${ }^{208}$ The texts in question record nativities that can

206 One can point to the various episodes in the Setne I and II Cycles in which protagonists copy magical manuscripts, which they are supposed to use as a model. See Love 2020 for a discussion of the such practices in the two narratives. The topic in the temple environment is also discussed by Wespi 2016: 184-185. Two papyrus letters, P.Carlsberg 21 and 22 (Zauzich 2000: 53-57), also relate to copying practices. The first text states that someone has borrowed two medical works, presumably so that he could copy them for his own use. In the second case, however, it seems that someone prepared copy for another person rather than replicating the source for himself.

207 Cf. Jones 1999a: 1.249 and 1.260 (P.Oxy.Astron. 4247). See also the so-called Horoscopes of Anubion (e.g. Heilen 2015: 265-266).

208 Winkler 2018: 304, nn. 34-35. Sandra Lippert informed me that during the excavations at Athribis she found further examples of such texts proving their provenance. Winkler 2018: 300, n. 18 , erroneously stated that they were Theban. Some of the suggestions made for readings can also now be corrected: e.g. the sign D1, which was misinterpreted as Leo, is in fact Aries and the one indicating the planet Mars cannot be read as suggested, but it is correct that it represents said planet. 
be dated from the early years of Queen Cleopatra VII (O.Ashm.Dem. 641) until the later parts of the reign of Augustus (O.Ashm.Dem. 634), a time span that covers roughly half a century. As such the corpus contains the oldest extant nativities from Egypt. ${ }^{209}$ Nevertheless, one should not automatically assume that the horoscopes were composed near the birth date recorded. The texts with nativities dating to the Ptolemaic period could well have been written during the Roman era. ${ }^{210}$

Unlike most horoscopes written in Egyptian, which can only be described as simple horoscopes, the Athribis texts testify to an advanced level of astrology. In addition to listing the standard information found in a basic horoscope, they provide the longitudes of the planets in each zodiac sign and state in which terms they were. The texts also consider prenatal syzygies of the Moon and relate them to the year of the lunar cycle. ${ }^{211}$ In addition to the four cardinal points, they also include calculations of several astrological lots, such as the Lot of Fortune (špšy.t) and the Lot of the Daimon $\left(\check{S}_{3} w\right){ }^{212}$

The texts are written in a combination of Demotic and Hieratic. Though most writings of the names of the planets or the zodiac signs are condensed down to one sign, the principles that were followed can be compared to those employed in the

209 The Greek horoscope BKT X 29 records a nativity that can be dated to $29 \mathrm{BC}$; then there is a leap of almost two decades before the next example, $B G U$ III 957, from $10 \mathrm{BC}$.

210 O.Ashm.Dem. 641 records a nativity from $48 \mathrm{BC}$ and contains the following dating formula:

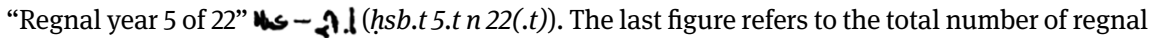
years of Cleopatra VII. Since the length of her reign would have been unknown prior to her death, the text must have been written no earlier than the reign of Augustus. Though the ideal might have been for younger children to be taken to diviners to have their futures predicted, it is clear that people went to astrologers as adults or at least in their adolescence. The same can be inferred from, for instance, P.Berlin 8279. The sign entry almanac must have been written down some time after AD 42 but the preserved dates belong to the reign of Augustus: 18 BC until AD 12 (e.g. Quack 2014b: 89). See also, n. 207 above.

211 See, for instance, O.Ashm.Dem. 633, which dates to regnal year 8 of Cleopatra VII (22 April 44 $\mathrm{BC}$ ), and mentions lunar year 13 (hsb.t 13(.t)); the cycle began in $57 \mathrm{BC}$. The position of the Moon is stated in 1.4 as $20.5^{\circ}$ in Gemini, and defined as the terms of Mars. Then another position is provided as $6^{\circ}$ in Libra. The latter position is again defined as in the terms of a planet, namely Saturn. The position coincides fairly accurately with the previous full Moon with respect to the date of birth. Other texts belonging to the same group further indicate the triplicity of the prenatal syzygy. There are also later Greek examples of horoscopes that take the prenatal syzygies into consideration when establishing a horoscope (Gieseler Greenbaum and Jones 2017).

212 For the lots, see Bouché-Leclercq 1899: 288-297; Neugebauer and van Hoesen 1959: 8-9; Heilen 2015: 1158-1182; Gieseler Greenbaum 2016. In the present corpus these should not be confused with the places of the Dodecatropos, which are referred to in similar ways. The shared terminology suggests a close connection behind the two concepts. This will be expanded upon elsewhere. 
contemporary monumental inscriptions found on temple walls. Not only does this indicate a higher level of writing knowledge (at least as far as can be judged from the rather abbreviated writing found in the horoscopes), but the way several names are written also connects to theological doctrines, which stresses the sacerdotal schooling of the astrologers who compiled these horoscopes.

It is clear that the texts were written by a number of individuals and that they record nativities up to approximately half a century apart. Unfortunately, it is not known if they were active at the same time or in succession. Since the texts offer only a limited repertoire of signs, it is difficult to assess how many scribes were involved, but at least two of the texts, O.Ashm.Dem. 519 and 741, appear to be signed by the astrologers who compiled them, a rare feature among such materials. ${ }^{213}$ Unfortunately, both texts are fragmentary. The first sherd contains two partially preserved horoscopes. One can be fairly precisely dated because of the reported planetary positions, which point to $36 \mathrm{BC}$, while the other contains a reference to the 10th year of a lunar cycle. The preserved astronomical information suggests a date in 23/22 BC. The second text can be tentatively dated to the first quarter of $19 \mathrm{BC}$ based on the preserved planetary positions.

Two individuals appear as potential practitioners. Harnouphis, the superior

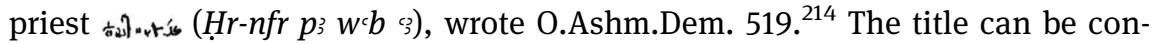
nected with priests who accessed the inner sanctum and were responsible for the daily ritual. As noted above, the superior priests had access to the higher echelons of sacerdotal education, even if they were not the highest-ranking temple dignitaries. ${ }^{215}$ The name and title is placed at the left edge of the text. On its own, it could hypothetically be taken as that of the native, particularly given that adults also sought the advice of astrologers. Clients could be mentioned by titles as is known from, for example, O.Glasg.Dem. 1925.96, which derives from Roman Memnoneia ${ }^{216}$ and was produced for Belles, son of Pasemis, the chief pastophoros (hry iry-s). ${ }^{217}$ There, however, the name of the native and that of his father, who is mentioned with the title, are written where expected: after the dating formula. The horoscopes from Athribis that mention the natives by name regularly do so in the same place. O.Ashm.Dem. 741 seems to confirm the

213 See Heilen 2020a: 431; Hübner 2020: 310.

214 See also Capponi 2017: 161.

215 See $n .82$ above.

216 Quack 2008/2009: 104-112.

217 If the father himself did not compile the horoscope, the instance is a reminder that not all temple servants engaged in, or had access to, astral knowledge. For the title in question, see Hoffmann and Quack 2014: 127-155. 
assumption that Harnouphis was the compiler of O.Ashm.Dem. $519 .^{218}$ The last lines of O.Ashm.Dem. 741, which follow the astronomical information, provide a name and a title. The name, which is partially preserved on the penultimate line of the text, is probably best reconstructed as Apollonios. Only the first four letters are preserved before the text breaks off: $3 p l[n]\left[-:: \% 2 x_{0}^{219}\right.$ The last line containing the title is faded, but one can still see that he was styled as the chief pastophoros. $^{220}$

These horoscopes were probably kept in the archives of the temple, and therefore not handed out to the customers. As indicated above, at least one piece found in the Ashmolean Museum (O.Ashm.Dem. 519) contains two horoscopes on one ostracon. ${ }^{221}$ One can only speculate about the relation between the two nativities. It is possible that these texts were kept by the practitioners in case the customer came back and asked for another prognostication for the same horoscope. Instead of redoing the calculations, the astrologer could turn to his files in order to check the positions before conducting a new astrological consultation. A potential factor as to why these particular horoscopes were kept by the astrologers is that it was cumbersome to compile them, more so than most known horoscopes of the basic type. On the other hand, the far simpler horoscopes from Narmouthis were also preserved by the temple personnel. ${ }^{222}$

Why the names of the practitioner were added is unclear. It is possible that this was done for archival purposes, to hold the astrologer accountable for his calculations. Another possibility is that the compilers took pride in their work in much the same way as Titus Pitenius probably did when he produced his horoscope for Hermon (P.Lond. I 130). S. Heilen understands his methods as an attempt to imitate Egyptian practices and the prelude to the horoscope as a bid to connect himself to the sages of Egypt. ${ }^{223}$ Titus wanted to make known that he was well versed in this type of intellectual pursuit.

218 Note that neither text is fully intact, and in both cases the dating formula in the first line(s) is lacking.

219 Even if the name is Greek, it says little about the ethnicity of the holder, especially since no patronym is preserved. The name appears to have been common in this locality as well as having been borne by both Egyptians and by those who identified as Greek.

220 Another poorly preserved word follows that is difficult to interpret.

221 Cf. Jones 1999a: 1.249.

222 Gallo 1997: xxxiii-xxxiv; Naether and Ross 2008: 84; Ross 2020: 518-521. For the horoscopes from Memnoneia, Neugebauer 1943: 120 assumed that they too belonged to an archive, while Quack 2008/2009: 111 asserts that the ostraca come from private contexts and that the finds represent the expected distribution of such texts across a settlement of that type.

223 Heilen 2020b: 263 and 265. 
Be this as it may, these texts, just as several others, suggest that there were a number of individuals who were able to act as astrological practitioners in the temples, and that they were scattered among various priestly ranks, confined neither to the low-ranking pastophoroi or regular priests, nor only to the highest echelons.

\section{Conclusion}

Although the Egyptians engaged in divination, including techniques relating to various heavenly phenomena, at least from the time of the New Kingdom, astrology came into vogue during the Graeco-Roman period. Right from the beginning there appear to have been specialists of various techniques of divination, including prognostication based on celestial phenomena. Such activities, however, left only a small impression on the textual record of the practitioners. Although individual inscriptions relate to astronomical practices throughout the Pharaonic period, it is not until shortly before the Graeco-Roman era that more detailed clues emerge about the kind of astral knowledge that these specialists possessed and about the different practices which they pursued in connection with astrology or celestial divination.

In the private inscriptions, astronomical knowledge was treated with more reverence than astrological knowledge, as far as such a division can be made. This may seem strange, considering that, for instance, temples were decorated with zodiacs. The inscriptions, however, usually stress cultic roles of the owner, a function that astrology largely seems to lack. The explanation for this lies in the fact that the temple zodiacs, although based on the same doctrines as the astrology practiced by the Egyptians, did not primarily serve a divinatory purpose. They depicted the moment of creation and as such had a theological relevance. The situation is similar with tombs and coffins adorned with depictions of zodiacs arranged so as to fit the date of birth of the tomb owner. Rather than primarily being a "hidden horoscope" disclosing the life lived by the occupant, they assisted his or her rebirth in the hereafter by recreating the moment of the original birth. Tombs were, after all, modelled on the temples and they partially fulfilled a similar purpose. The evidence posed by inscriptions, documentary texts, and the manuals themselves sheds light on the temple zodiacs and those found on coffins and in tombs. $^{224}$ The theological innovation depicted by these monuments was not

224 Since the zodiacs provide a date of birth of the tomb owner, one can only speculate about any potential connection to the practice of providing a precise birth date in a few Ptolemaic-period autobiographies. That the latter referred to horoscopic practices is disputed, however (see n. 2 above). 
elusive knowledge. It was part of the repertoire that came with becoming a priest and thus must, unsurprisingly, have been understood by a large proportion, if not all, of the temple personnel as well as the tomb owners. ${ }^{225}$ The related art of divination, astrology, received part of its credibility through the prominence of astral knowledge in the temples and its significance in theological doctrines. This connection can also be seen in the fact that the practitioners held epithets and titles associated with the divine patrons of these arts, such as Imhotep, or gods like Thoth. They claimed to possess the same type of knowledge as the legendary sages, and used them to model their activity. The underlying perceptions of the sages may, in fact, be understood as idealised reflections of the practitioners about their own role as scholars. They stressed their knowledge of the mechanics of the skies and thus also of the world's constitution.

Numerous textual and material artefacts from Graeco-Roman Egypt demonstrate the importance of astrology to Egyptian culture. That the lion's share of traceable astrologers can be tied to the temple environment has long been known, but the discussion here has fleshed out and detailed that connection. As astral knowledge turns out to have been widely accessible to the temple personnel, irrespective of position, its practitioners can be found among priests of many types and different ranks. Engaging in astral science could not only generate supplementary income for the temple servants, but also provide them with additional social authority because it enabled them to extend their services into the realm of popular religion. Astrologers who engaged in natal horoscopy clearly had an interest in making universal forecasts as well and their activities did not end there. They were also engaged in several other areas of "science", which accords well with the image of the Egyptian priest provided by many a Greek and Latin author as a learned "polymath" versed in all sorts of "arcane" wisdom. To the priesthood as a collective, however, it was hardly arcane.

Acknowledgment: This paper was finished in the framework of the project "Ancient Astral Science in Transformation: Zodiac” (885478) financed by the European Research Council under its Horizon 2020 program, Advanced Grant scheme.

\section{References}

Altmann, V. 2010. Die Kultfrevel des Seth: die Gefährdung der göttlichen Ordnung in zwei Vernichtungsritualen der ägyptischen Spätzeit (Urk. VI). SSR 1. Wiesbaden: Harrassowitz.

225 von Lieven 2020: 417 suggests that they could have been commissioned by the owner themselves since many of them carried sacerdotal titles. 
Altmann-Wendling, V. 2018. Mondsymbolik - Mondwissen. Lunare Konzepte in den ägyptischen Tempeln griechisch-römischer Zeit. SSR 22. Wiesbaden: Harrassowitz.

Altmann-Wendling, V. 2019. "Shapeshifter - Knowledge of the Moon in Graeco-Roman Egypt.” In Finding, Inheriting or Borrowing? The Construction and Transfer of Knowledge in Antiquity and the Middle Ages, edited by J. Althoff, D. Berrens, and T. Pommerening, 213-52. MHK 39. Bielefeld: Transcript-Verlag.

Altmann-Wendling, V., and M. Stockhusen. 2020. "Die Statue eines ägyptischen Priesters und Astronomen (JE 38545)." In Zeit in den Kulturen des Altertums. Antike Chronologie im Spiegel der Quellen, edited by R. Färber, and R. Gauschy, 103-15. Cologne: Böhlau.

Ashby, S. 2020. Calling out to Isis: The Enduring Nubian Presence at Philae. GSANE 13. Piscataway, N): Georgias Press.

Baines, J. 2020. "From Living a Life to Creating a Fit Memorial." In Ancient Egyptian Biographies: Contexts, Forms, Functions, edited by J. Stauder-Porchet, E. Frood, and A. Stauder, 47-83. WilbStud 6. Atlanta, GA: Lockwood Press.

Bastianini, G., and C. Gallazzi. 1990. "Dati per un oroscopo: O. Tebt. NS inv. 89/1." Tyche 5: 5-7.

Beck, R. 2013. "Imagery and Narrative in an Ancient Horoscope: P.Lond. 130 (Greek Horoscopes No. 81)." JSRNC 7: 397-406.

Beinlich, H. 2014. "Das Buch vom Fayum." In Die Entstehung der Welt. Schöpfungsmythen aus dem Alten Ägypten nach dem Buch vom Fayum, edited by H. Beinlich, R. Schultz, and A. Wieczorek, 27-77. Dettelbach: J.H. Röll Verlag.

Birk, R. 2014. "Titel-Bilder: zur amtsspezifischen Ikonographie thebanischer Priester der Ptolemäerzeit.” In Bild: Ästhetik - Medium - Kommunikation. Beiträge des dritten Münchner Arbeitskreises Junge Ägyptologie (MAJA 3), 7. bis 9.12.2012, edited by G. Neunert,

A. Verbovsek, and K. Gabler, 79-101. GOF IV 58. Wiesbaden: Harrassowitz.

Birk, R. 2020. Türöffner des Himmels: Prosopographische Studien zur thebanischen Hohepriesterschaft der Ptolemäerzeit. ÄA 76. Wiesbaden: Harrassowitz.

Birk, R. "Thebanische Astronomen der Prolemärerzeit (I): Das Dosier des Harmais (Kairo, TR 25/10/ 17/5 und JE 43625)." In Documents de théologies thébaines tardives (D3T 4), edited by Ch.Thiers. CENiM. Montpellier: Université Paul Valery. (forthcoming).

Bohleke, B. 1996. "In Terms of Fate: A Survey of the Indigenous Egyptian Contribution to Ancient Astrology in Light of Papyrus CtYBR inv. 1132(B)." SAK 23: 11-46.

Borchardt, L. 1899. "Ein altägyptisches astronomisches Instrument." ZÄS 37: 10-7.

Bosticco, S. 1965. Museo Archeologico di Firenze: le stele egiziane del Nuovo Regno. Cataloghi dei musei e gallerie d'Italia. Roma: Istituto poligrafico dello Stato.

Bouché-Leclercq, A. 1899. L'astrologie grecque. Paris: Leroux.

Brunner, H. 1973. "Zeichendeutung aus Sternen und Winden in Ägypten.” In Wort und Geschichte: Festschrift für Karl Elliger zum 70. Geburtstag, edited by H. Gese, and H. P. Rüger, 25-30.

AOAT 18. Kevelaer: Butzon \& Bercker.

Cannuyer, Ch. 2010. La girafe dans l'Égypte ancienne et le verbelo :étude de lexicographie et de symbolique animalière. AcOr Belgica, subsidia 4. Bruxelles: Société Belge d’Études Orientales.

Capponi, L. 2017. Il ritorno della fenice. Intellettuali e potere nell'Egitto romano. Studi i testi 23. Pisa: Edizioni ETS.

Cauville, S. 2010. “Imhotep: un avatar de Thot." GM 224: 17-26.

Černý, J. 1976. Coptic Etymological Dictionary. Cambridge: Cambridge University Press.

Chauveau, M. 1992. “Un traité d'astrologie en écriture démotique.” CRIPEL 14: 101-5. 
Clagett, M. 1995. Ancient Egyptian Science, vol. 2: Calendars, Clocks, and Astronomy. MAPS 214. Philadelphia: American Philosophical Society.

Collombert, Ph. 2014. "Omina brontoscopiques et pluies de grenouilles." In Acts of the Tenth International Congress of Demotic Studies, Leuven, 26-30 August 2008, edited by Y. Broux, and M. Depauw, 15-26. OLA 231. Leuven: Peeters.

Coulon, L. 2006. “Les sièges de prêtre d'époque tardive: à propos de trois documents thébains." RdÉ 57: 1-31.

Cumont, F. 1937. L'Égypte des astrologues. Brussels: Fondation Égyptologique Reine Elisabeth.

Daoud, K. 1993. "An early Ramesside Stela of a Chief of Hour Watchers in the Memphite Temple of Ptah.” JEA 79: 261-65.

Daressy, G. 1919. “Antiquités trouvées à Fostat.” ASAE 17/18: 274-78.

de Meulenaere, H. 1955. "Une formule des inscriptions autobiographiques de basse époque." In Ägyptologische Studien. Hermann Grapow zum 70. Geburtstag gewidmet, edited by

0. Firchow, 219-31. Berlin: Deutsche Akademie der Wissenschaften.

Demichelis, S. 2002. “La divination par l'huile a l'époque ramesside." In La magie en Égypte : à la recherche d'une définition. Actes du colloque organisé par le Musée du Louvre les 29 et 30 septembre 2000, edited by Y. Koenig, 149-65. Paris: Documentation Française.

Depauw, M. 2001. "A Stela of an Astronomer." Enchoria 27: 1-2.

Depuydt, L. 1994. “A Demotic Table of Terms.” Enchoria 21: 1-9.

Depuydt, L. 1998a. “The Demotic Mathematical Astronomical Papyrus Carlsberg 9 Reinterpreted.” In Egyptian Religion: The Last Thousand Years: Studies Dedicated to the Memory of Jan Quaegebeur, Vol. 2, edited by W. Clarysse, A. Schoors, and H. Willems, 1277-97. OLA 85. Leuven: Peeters.

Depuydt, L. 1998b. “Gnomons at Meroë and Early Trigonometry." JEA 84: 171-80.

Depuydt, L. 2016. "The Regnal Years of the "Mathematical Astronomical" Demotic Papyrus Carlsberg 9 Reinterpreted." In Rich and Great: Studies in Honour of Anthony J. Spalinger on the Occasion of his 70th Feast of Thot, edited by R. Landgráfová, and J. Mynářová, 39-60. Prague: Charles University in Prague, Faculty of Arts.

Derchain, P. 1989. “Harkhébis, le psylle-astrologue.” CdÉ 64: 74-89.

Derchain-Urtel, M.-Th. 1989. Priester im Tempel: die Rezeption der Theologie der Tempel von Edfu und Dendera in den Privatdokumenten aus ptolemäischer Zeit. GOF IV 19. Wiesbaden: Harrassowitz.

Dhennin, S. 2012. “Une stèle de Mefkat (Montgeron 2007.4)." RdÉ 63: 67-78.

Dieleman, J. 2003. “Claiming the Stars: Egyptian Priests Facing the Sky.” In Basel Egyptology Prize 1: Junior Research in Egyptian History, Archaeology, and Philology, edited by S. Bickel, and A. Loprieno, 277-89. AH 17. Basel: Schwabe.

Dieleman, J. 2005. Priests, Tongues, and Rites: The London-Leiden Magical Manuscripts and Translation in Egyptian Ritual (100-300 CE). RGRW 153. Leiden: Brill.

Escolano-Poveda, M. 2018/2019. “Astronomica Montserratensia I: A Demotic Monthly Almanac with Synodic Phenomena (P.Monts.Roca inv. 314).” Enchoria 36: 1-36.

Evans, J. A. S. 1961. A Social and Economic History of an Egyptian Temple in the Graeco-Roman Period. YES 17. New Haven: Yale University Press.

Evans, J. 2004. “The Astrologer's Apparatus: A Picture of Professional Practice in Greco-Roman Egypt." JHA 34: 1-44.

Fissolo, J.-L. 2001. “Les astronomes égyptiens." ÉAO 21: 15-24.

Gallo, P. 1997. Ostraca demotici e ieratici dall'archivio bilingue di Narmouthis II (nn. 34-99). Pisa: Edizioni ETS. 
Gautschy, R. 2020. "Die Astronomen." In Texte zur Wissenkultur, edited by B. Janowski, and D. Schwemer, 370. TUAT N.F. 9. Gütersloh: Gütersloher Verlagshaus.

Gieseler Greenbaum, D. 2016. The Daimon in Hellenistic Astrology: Origins and Influence. AMD 11. Leiden: Brill.

Gieseler Greenbaum, D. 2020. “The Hellenistic Horoscope.” In Hellenistic Astronomy: The Science in its Context, edited by A. C. Bowen, and F. Rochberg, 443-71. Leiden: Brill.

Gieseler Greenbaum, D., and A. Jones. 2017. "P.Berl. 9825: An Elaborate Horoscope for 319 CE and its Significance for Greek Astronomical and Astrological Practice.” ISAW Papers 12: 1-58.

Gieseler Greenbaum, D., and M. Ross. 2015. "Various Renderings of חív $\alpha \xi$ in Greek and Demotic at Meīdinet Māḍi." In Astrology in Time and Place: Cross-Cultural Questions in the History of Astrology, edited by N. Champion, and D. Greenbaum, 109-29. Cambridge: Cambridge Scholars Publishing.

Graefe, E. 1971. Untersuchungen zur Wortfamilie bj3. PhD-Thesis. Cologne: University of Cologne. Guermeur, I. 2003. “Glanures (§ 1-2).” BIFAO 103: 281-96.

Guermeur, I. 2005. Les cultes d'Amon hors de Thèbes: recherches de géographie religieuse. BEHE SSR 123. Turnhout: Brepols.

Gury, F. 1996. "Le métier d'astrologue." In L'Africa Romana. Atti dell'XI convegno di studio (Cartagine, 15-18 dicembre 1994).”, edited by M. Khanoussi, P. Ruggieri, and C. Vismara, 231-59. Ozieri: Editrice II Torchietto.

Heilen, S. 2010. “Ptolemy's Doctrine of the 'Terms' and its Reception.” In Ptolemy in Perspective. Use and Criticism of his Work from Antiquity to the Nineteenth Century, edited by A. Jones, 45-93. Archimedes 23. Dordrecht and New York, NY: Springer.

Heilen, S. 2015. 《Hadriani genitura》》: die astrologischen Fragmente des Antigonos von Nikaia. TuS 43. Berlin and Boston, MA: De Gruyter.

Heilen, S. 2016. "Translating Greco-Roman Astrological Texts: The Horoscope of Hadrian by Antigonus of Nicaea." In Translating Writings of Early Scholars in the Ancient Near East, Egypt, Greece and Rome, edited by A. Imhausen, and T. Pommerening, 507-69. BzA 344. Berlin and Boston, MA: De Gruyter.

Heilen, S. 2020a. "Hellenistic Horoscopes in Greek and Latin: Contexts and Uses." In Hellenistic Astronomy: The Science in its Context, edited by A. C. Bowen, and F. Rochberg, 428-46. Leiden: Brill.

Heilen, S. 2020b. "Short Time in Greco-Roman Astrology." In Down to the Hour: Short Time in the Ancient Mediterranean and the Near East, edited by K. J. Miller, and S. L. Symons, 239-70. TAC 8. Leiden: Brill.

Herbin, F.-R. 2008. Books of Breathing and Related Texts. CBD 4. London: British Museum. Hoffmann, F. 1995. “Astronomische und astrologische Kleinigkeiten I: Pap. Wien D 6005.” Enchoria 22: 22-6.

Hoffmann, F. 1997/1998. "Astronomische und astrologische Kleinigkeiten II: P. Heidelberg Inv. Dem. 40 und 41." Enchoria 24: 34-7.

Hoffmann, F. 1999. “Astronomische und astrologische Kleinigkeiten III: P. Berlin P 23547.” Enchoria 25: 24-6.

Hoffmann, F. 2010. "Astronomische und astrologische Kleinigkeiten VI: Neumonddaten aus dem Jahre 184/185 n. Chr." In Honi soit qui mal y pense. Studien zum pharaonischen, griechischrömischen und spätantiken Ägypten zu Ehren von Heinz-Josef Thissen, edited by Ch. Leitz, D. von Recklinghausen, and H. Knuf, 233-36. OLA 194. Leuven: Peeters.

Hoffmann, F. 2014. "Internationale Wissenschaft im hellenistischen Ägypten.” In Orient und Okzident in hellenistischer Zeit. Beiträge zur Tagung "Orient und Okzident - Antagonismus 
oder Konstrukt? Machtstrukturen, Ideologien und Kulturtransfer in hellenistischer Zeit", Würzburg 10.-13. April 2008, edited by F. Hoffmann, and K. S. Schmit, 77-112. Vaterstetten: Patrick Broze.

Hoffmann, F. 2016. "Beispiele für Übersetzung und Kommentierung ägyptischer astronomischer Texte: Sonnenuhr, Sonnenaufgang und Dekansterne." In Translating Writings of Early Scholars in the Ancient Near East, Egypt, Greece and Rome, edited by A. Imhausen, and T. Pommerening, 335-78. BzA 344. Berlin and Boston, MA: De Gruyter.

Hoffmann, F. 2017. "Astronomische und astrologische Kleinigkeiten VII. Die Inschrift zu Tagesund Nachtlängen aus Tanis." In Illuminating Osiris: Egyptological Studies in Honor of Mark Smith, edited by R. Jasnow, and Gh. Widmer, 135-53. MVCAE 2. Atlanta, GA: Lockwood Press. Hoffmann, F., and A. Jones. 2006/2007. “Astronomische Kleinigkeiten V: Die Mondephemeride des P. Carlsberg 638 / Dating and Method of Computation." Enchoria 30: 10-20.

Hoffmann, F., and J. F. Quack. 2014. "Pastophoros." In A Good Scribe and an Exceedingly Wise Man: Studies in Honour of W.J. Tait, edited by A. M. Dodson, J. J. Johnston, and W. Monkhouse, 127-55. GHE 21. London: Golden House Publications.

Hübner, W. 2020. “The Professional áctpoגóyoc.” In Hellenistic Astronomy: The Science in Its Contexts, edited by A. C. Bowen, and F. Rochberg, 297-320. Leiden: Brill.

Hughes, G. R. 1951. “A Demotic Astrological Text.” JNES 10: 256-64.

Hughes, G. R. 1986. “An Astrologer's Handbook in Demotic Egyptian.” In Egyptological Studies in Honor of Richard A. Parker: Presented on the Occasion of his 78th Birthday December 10, 1983, edited by L. H. Lesko, 53-69. Hanover and London: University Press of New England.

Jacquet-Gordon, H. 2003. The Temple of Khonsu Vol. III-The Graffiti on the Khonsu Temple Roof at Karnak: A Manifestation of Personal Piety. OIP 123. Chicago, IL: The Oriental Institute of the University of Chicago.

Jasnow, R. 2010. "On Sothis and the So-Called Clepsydra (?) in the Book of Thoth (B02, 3/16 4/11)." In Honi soit qui mal y pense. Studien zum pharaonischen, griechisch-römischen und spätantiken Ägypten zu Ehren von Heinz-Josef Thissen, edited by Ch. Leitz, D. von Recklinghausen, and H. Knuf, 273-43. OLA 194. Leuven: Peeters.

Jansen-Winkeln, K. 2007. Inschriften der Spätzeit, vol. 2: Die 22.-24. Dynastie. Wiesbaden: Harrassowitz.

Jones, A. 1994. "The Place of Astronomy in Roman Egypt." Apeiron 27/4: 25-52.

Jones, D. 1998. “4471: Omens from the Rising of Sirius.” In The Oxyrhynchus Papyri 65, edited by M. W. Haslam, 130-33. EES GRM 85. London: Egypt Exploration Society.

Jones, A. 1999a. Astronomical Papyri from Oxyrhynchus. MAPS 233. Philadelphia, PA: American Philosophical Society.

Jones, A. 1999b. "A Classification of Astronomical Tables on Papyrus." In Ancient Astronomy and Celestial Divination, edited by N. M. Swerdlow, 299-340. Cambridge MA and London: MIT Press.

Jones, A. 2007. "Astrologers and their Astronomy." In Oxyrhynchus: A City and its Texts, edited by A. K. Bowman, R. A. Coles, N. Gonis, D. Obbink, and P. J. Parsons, 307-14. EES GRM 93. London: Egypt Exploration Society.

Jones, A. 2012. "An Astronomical Almanac." In Inediti offerti a Rosario Pintaudi per il suo $65^{\circ}$ compleanno (P.Pintaudi), edited by D. Minutoli, 56-60. Florence: Gonnelli.

Jones, A., and M. Perale. 2011. "Two Astronomical Tables from the Tebtunis Temple Library." Comunicazioni 9: 39-51.

Jones, A., and M. Perale. 2012. "Greek Astronomical Tables in the Papyrus Carlsberg Collection." AfP 58: 308-43. 
Koch, U. S. 2015. Mesopotamian Divination Texts: Conversing with the Gods. Sources from the First Millennium BCE. GDMTR 7. Münster: Ugarit-Verlag.

Krauss, R. 2007. "Die Bubastiden-Finsternis im Licht von 150 Jahren Forschungsgeschichte.” MDAIK 63: 211-23.

Lacovara, P. 2005. "Fragment of a Zodiac." In Excavating Egypt: Great Discoveries from the Petrie Museum of Egyptian Archaeology, University College London, edited by B. Teasly-Trope, S. Quirke, and P. Lacovara, 110. Atlanta, GA: Michael C. Carlos Museum - Emory University. Leitz, Ch. 1994. Tagewählerei: das Buch ḥ3.t nḥ̣ ph.wy d.t und verwandte Texte. ÄA 55.

Wiesbaden: Harrassowitz.

Leitz, Ch. 1995. Altägyptische Sternuhren. OLA 62. Leuven: Peeters.

Leitz, Ch. 2006. "Die Sternbilder auf dem rechteckigen und runden Tierkreis von Dendara." SAK 34: 285-318.

Leroux, N. 2018. Les recommandations aux prêtres dans les temples ptolémaïques et romains: esquisse d'un héritage culturel et religieux. SSR 21. Wiesbaden: Harrassowitz.

Lippold, G. 1931. “Melampus.” In Paulys Realencyklopädie classischen Altertumswissenschaft 15/ 1, edited by G. Wissowa, 392-405. Stuttgart: J. B. Metzlersche Verlagsbuchhandlung.

Logan, Th., and B. Williams. 2000. "On the Meroe Observatory." BzS 7: 59-84.

Love, E. O. D. 2016. Code-Switching with the Gods: The Bilingual (Old Coptic-Greek) Spells of PGM IV and their Linguistic, Religious, and Socio-Cultural Context in Late Roman Egypt. ZÄS Beih. 4. Berlin and Boston, MA: De Gruyter.

Love, E. O. D. 2020. "The Literary vs the Literal: The Narration of Magical Practices, Texts, and their Practitioners in Setne I and II Compared with the So-Called Demotic and Greek Magical Papyri." ISAW Papers 18.5: 1-51.

Lull, J. 2004. "En torno a la figura del sacerdote-astronómico Egipcio." BAEE 14: 63-78.

Menchetti, A. 2009. "Un aperçu des textes astrologiques de Médinet Madi." In Actes du IXe Congrès International des Études Démotiques: Paris, 31 août - 3 septembre 2005, edited by Gh. Widmer, and D. Devauchelle. BdÉ 147. Cairo: IFAO.

Menchetti, A., and R. Pintaudi. 2007. "Ostraka greci e bilingui da Narmuthis.” CdÉ 82: 227-80.

Menchetti, A., and R. Pintaudi. 2010. "L’orologio solare di Medinet Madi.” CdÉ 85: 269-77.

Mertens, M. 1989. "Pourquoi Isis est-elle appelée профп̃tıc." CdÉ 64: 260-66.

Moje, J. 2014. "Priesterliches Kultwissen in den philensischen Graffiti des 4. und 5. Jahrhunderts n. Chr." In Esoteric Knowledge in Antiquity, edited by K. Geus, and M. Geller, 121-47. Berlin: Max-Planck-Institut für Wissenschaftsgeschichte.

Moyer, I. 2011. Egypt and the Limits of Hellenism. Cambridge: Cambridge University Press.

Naether, F., and M. Ross. 2008. "Interlude: A Series Containing a Hemerology with Lengths of Daylight.” EVO 31: 59-90.

Nagel, S. 2019. Isis im Römischen Reich, Teil I: Die Göttin im griechisch-römischen Ägypten. Philippika 109. Wiesbaden: Harrassowitz.

Nawotka, K. 2017. The Alexander Romance by Ps.-Callisthenes. Mnemosyne Suppl. 399. Leiden: Brill.

Nenna, M.-D. 2002. "De Douch (oasis de Kharga) à Grand (Vosges): un disque en verre peint à représentations astrologiques." BIFAO 102: 355-76.

Neugebauer, 0. 1942. "Egyptian Planetary Texts." TAPS N.S. 32: 209-50.

Neugebauer, 0. 1943. "Demotic Horoscopes." JAOS 63: 115-27.

Neugebauer, O., and H. B. van Hoesen. 1959. Greek Horoscopes. MAPS 48. Philadelphia, PA: American Philosophical Society.

Neugebauer, O., and R. A. Parker. 1968. "Two Demotic Horoscopes.” JEA 54: 231-35. 
Neugebauer, O., and R. A. Parker. 1969. Egyptian Astronomical Texts III: Decans, Planets, Constellations and Zodiacs. BEStud. 6. Providence, RI: Brown University Press.

Neugebauer, O., R. A. Parker, and K.-Th. Zauzich. 1981. “A Demotic Lunar Eclipse of the First Century B.C." PAPS 125: 312-27.

Osing, J. 1985. "Stundeneinteilung, -beobachter.” In Lexikon der Ägyptologie 6, edited by W. Helck, and W. Westendorf, 100-1. Wiesbaden: Harrassowtiz.

Ossendrijver, M. 2019. "Babylonian Market Predictions." In Keeping Watch in Babylon: The Astronomical Diaries in Context, edited by J. Haubold, J. Steele, and K. Stevens, 53-78. CHANE 100. Leiden: Brill.

Ossendrijver, M., and A. Winkler. 2018. "Chaldeans on the Nile: Two Egyptian Astronomical Texts with Babylonian Systems $A_{1}$ and $A_{2}$ for Mercury." In The Scaffolding of our Thoughts: Essays on Assyriology and the History of Science in Honor of Francesca Rochberg, edited by C. J. Crisostomo, E. A. Escobar, T. Tanaka, and N. Veldhuis, 382-419. AMD 13. Leiden: Brill. Papathomas, A. 2006. Fünfunddreissig griechische Papyrusbriefe aus der Spätantike. CPR 25. Munich and Leipzig: K.G. Saur.

Parker, R. A. 1959. A Vienna Demotic Papyrus on Eclipse- and Lunar-Omina. BEStud. 2. Providence, RI: Brown University Press.

Parker, R. A. 1974. "Ancient Egyptian Astronomy." PTRS Lond., Ser. A 276: 51-65.

Parker, R. A., and K-Th. Zauzich. 1981. "The Seasons in the First Century BC." In Studies Presented to Hans Jakob Polotsky, edited by D. W. Young, 472-79. East Gloucester, MA: Pirtle \& Polson.

Perpillou-Thomas, F. 1993. Fêtes d'Égypte ptolémaïque et romaine d'après la documentation papyrologique grecque. StudHell 31. Leuven: Peeters.

Peust, C. 2014. "Towards a Typology of Poetic Rhyme: with Observations of Rhyme in Egyptian." In Egyptian-Coptic Linguistics in Typological Perspective, edited by E. Grossman, M. Haspelmath, and T. S. Richter, 341-85. EALT 55. Berlin and Boston, MA: De Gruyter.

Pfeiffer, S. 2018. "Comments on the Egyptian Background of the Priests' Procession during the Navigium Isidis." In Individuals and Materials in the Greco-Roman Cults of Isis: Agents, Images, and Practices, edited by V. Gasparini, and R. Veymiers, 672-89. RGRW 187. Leiden: Brill.

Pope, J. 2008/2009. “The Demotic Proskynema of a Meroïte Envoy to Roman Egypt (Philae 416).” Enchoria 31: 68-103.

Pries, A. 2011. Die Stundenwachen im Osiriskult: eine Studie zur Tradition und Späten Rezeption von Ritualen im Alten Ägypten. SSR 2. Wiesbaden: Harrassowitz.

Quack, J. F. 2002a. “Die Spur des Magiers Petese.” CdÉ 77: 76-92.

Quack, J. F. 2002b. “Die Dienstanweisung des Oberlehrers im Buch vom Tempel.” In 5. Ägyptologische Tempeltagung Würzburg, 23-26. September 1999, edited by H. Beinlich, J. Hallof, and H. Hussy, 159-71. ÄAT 33/3. Wiesbaden: Harrassowitz.

Quack, J. F. 2003. "Le manuel du temple: une nouvelle source sur la vie des prêtres égyptiens." ÉAO 29: 11-8.

Quack, J. F. 2008. “Texte aus Ägypten: demotische, magische und divinatorische Texte.” In Omina, Orakel, Rituale und Beschwörungen, edited by B. Janowski, and B. Wilhelm, 331-84. TUAT N.F. 4. Gütersloh: Gütersloher Verlagshaus.

Quack, J. F. 2008/9. “Ein astrologisches Ostrakon der frühen Kaiserzeit (oGlasgow D 1925.96).” Enchoria 31: 104-12.

Quack, J. F. 2010. “The Naos of the Decades and its Place in Egyptian Astrology.” In Alexandria and the North-West Delta. Joint Conference Proceedings of Alexandria: City and Harbour (Oxford 2004) and The Trade, Topography and Material Culture of Egypt's North-West Delta, 8th 
Century BC to 8th Century AD (Berlin 2006), edited by D. Robinson, and A. Wilson, 175-81. OCMA Mon. 5 Oxford: OCMA.

Quack, J. F. 2013. "Zu einigen demotischer Gruppen umstrittener Lesung oder problematische Ableitung." In Aspects of Demotic Orthography, edited by S. P. Vleeming, 99-116. StudDem 11. Leuven: Peeters.

Quack, J. F. 2014a. "Totenbuch und Getreideabrechnung: von der Vereinbarkeit von profanen und religiösen Texten auf einem Schriftträger im Alten Ägypten.” In Erscheinungsformen und Handhabungen heiliger Schriften, edited by D. C. Luft, and J. F. Quack, 111-35. Materiale Textkulturen 5. Berlin: De Gruyter.

Quack, J. F. 2014b. "Ein Festlied aus Soknopaiou Nesos.” In Gehilfe des Thot: Festschrift für KarlTheodor Zauzich zu seinem 75. Geburtstag, edited by S. L. Lippert, and M. A. Stadler, 89-94. Wiesbaden: Harrassowitz.

Quack, J. F. 2016. "On the Concomitancy of the Seemingly Incommensurable, or Why Egyptian Astral Tradition Needs to be Analyzed within Its Cultural Context." In The Circulation of Astronomical Knowledge in the Ancient World, edited by J. Steele, 230-44. TAC 6. Leiden: Brill.

Quack, J. F. 2017a. "On the Regionalization of Roman-Period Egyptian Hands.” In Scribal Repertoires in Egypt from the New Kingdom to the Early Islamic Period, edited by J. Cromwell, and E. Grossman, 184-210. Oxford and New York, NY: Oxford University Press.

Quack, J. F. 2017b. “'Assur Will Suffer’: Predicting Disaster in Ancient Egypt.” In Historical Disaster Experiences: Towards a Comparative and Transcultural History of Disasters Across Asia and Europe, edited by G. J. Schenk, 198-206. Cham: Springer.

Quack, J. F. 2018a. "Egypt as an Astronomical-Astrological Centre between Mesopotamia, Greece, and India." In The Interactions of Ancient Astral Science, edited by D. Brown, 69-123. Bremen: Hempen.

Quack, J. F. 2018b. "What is a Priest of Ëse, of Wusa, and of Isis in the Egyptian and Nubian World?" In Individuals and Materials in the Greco-Roman Cults of Isis: Agents, Images, and Practices, edited by V. Gasparini, and R. Veymiers, 108-26. RGRW 187. Leiden: Brill.

Quack, J. F. 2019. “The Planets in Ancient Egypt.” In Oxford Research Encyclopedia of Planetary Science. Oxford: Oxford University Press.

Quack, J. F., and K. Ryholt. 2019. "Petese Interpreting Astrology by Imhotep for King Nechepsos." In Demotic Literary Texts from Tebtunis and Beyond, edited by J. F. Quack, and K. Ryholt, 161-83. The Carlsberg Papyri 11. CNIP 36. Copenhagen: Museum Tusculanum.

Quaegebeur, J. 1995. "A la recherche du haut clergé thébain à l'époque gréco-romaine.” In Hundred-Gated Thebes: Acts of a Colloquium on Thebes and the Theban Area in the GraecoRoman Period, edited by P. W. Pestman, and S. P. Vleeming. PLBat 27, 139-61. Leiden: Brill.

Renberg, G. H. 2016. Where Dreams May Come True: Incubation Sanctuaries in the Greco-Roman World. RGRW 184. Leiden: Brill.

Reymond, E. A. E. 1977. From the Contents of the Libraries of the Suchos Temples in the Fayyum, Part II: From Ancient Egyptian Hermetic Writings. MPER N.S. 11. Vienna: Brüder Hollinek.

Rilly, C., and A. de Voogt. 2012. The Meroitic Language and Writing System. Cambridge and New York, NY: Cambridge University Press.

Ritner, R. K. 1993. The Mechanics of Ancient Egyptian Magical Practices. SAOC 54. Chicago, IL: Oriental Institute of the University of Chicago.

Ritner, R. K. 2009. The Libyan Anarchy: Inscriptions from Egypt's Third Intermediate Period. WAW 21. Atlanta, GA: Society of Biblical Literature. 
Rives, J. 2011. "Magicians and Astrologers." In The Oxford Handbook of Social Relations in the Roman World, edited by M. Peachin, 679-92. Oxford HandbooksOxford: Oxford University Press.

Roccati, A. 1984. “Lessico meteorologico.” In Studien zu Sprache und Religion Ägyptens zu Ehren von Wolfhart Westendorf, überreicht von seinen Freunden and Schülern, vol. 1, edited by F. Junge, 343-54. Göttingen: Selbstverlag.

Rochberg, F. 1998. Babylonian Horoscopes. TAPS N.S. 88. Philadelphia, PA: American Philosophical Society.

Ross, M. 2006. "An Introduction to the Horoscopic Ostraca of Medînet Mâdi." EVO 29: 47-80.

Ross, M. 2007. "A Continuation of the Horoscopic Ostraca of Medînet Mâdi." EVO 30: 151-70.

Ross, M. 2009. "Further Horoscopes from Medinet Madi." EVO 32: 61-95.

Ross, M. 2020. "Demotic Horoscopes." In Hellenistic Astronomy: The Science in its Context, edited by A. C. Bowen, and F. Rochberg, 510-26. Leiden: Brill.

Ryholt, K. 2005. "On the Contents and Nature of the Tebtunis Temple Library: A Status Report." In Tebtynis und Soknopaiu Nesos: Leben im römerzeitlichen Fajum. Akten des Internationalen Symposions vom 11. bis 13. Dezember 2003 in Sommerhausen bei Würzburg, edited by

S. L. Lippert, and M. Schentuleit, 141-70. Wiesbaden: Harrassowitz.

Ryholt, K. 2009. “The Life of Imhotep (P.Carlsberg 85)." In Actes du IXe Congrès International des Études Démotiques: Paris, 31 août - 3 septembre 2005, edited by Gh. Widmer, and D. Devauchelle, 305-15. BdÉ 147. Cairo: IFAO.

Ryholt, K. 2011. “New Light on the Legendary King Nechepsos of Egypt.” JEA 97: 61-72.

Ryholt, K. 2017. "Scribal Habits at the Tebtunis Temple Library." In Scribal Repertoires in Egypt from the New Kingdom to the Early Islamic Period, edited by J. Cromwell, and E. Grossman, 153-83. Oxford and New York, NY: Oxford University Press.

Ryholt, K. 2018. “Demotic Papyri from the Franco-Italian Excavations at Tebtunis 1988-2016." In Le Fayoum: Archéologie - Histoire - Religion. Actes du sixième colloque international, Montpellier, $26-28$ octobre 2016, edited by M.-P. Chaufray, 129-49. Wiesbaden: Harrassowitz.

Ryholt, K. 2019. “End of a Narrative with a Colophon.” In Demotic Literary Texts from Tebtunis and Beyond, edited by J. F. Quack, and K. Ryholt, 501-10. The Carlsberg Papyri 11. CNIP 36. Copenhagen: Museum Tusculanum.

Sauneron, S. 1959. “Le prêtre astronome du temple d’Esna.” Kêmi 15: 36-41.

Sauneron, S. 1960. The Priests of Ancient Egypt. Ithaca, NY: Cornell University Press.

Smith, M. 1985. "Lexicographical Notes on Demotic Texts II.” Enchoria 13: 103-14.

Smith, M. 1991. "Did Psammetichus I Die Abroad?" OLP 22: 101-9.

Smith, M. 2005. Papyrus Harkness: (MMA 31.9.7). Oxford: Griffith Institute.

Smith, M. 2009. Traversing Eternity: Texts for the Afterlife from Ptolemaic and Roman Egypt. Oxford: Oxford University Press.

Smith, M. 2017. Following Osiris: Perspectives on the Osirian Afterlife from Four Millennia. Oxford and New York, NY: Oxford University Press.

Smith, H. L., and N. W. Mitry. 1984. "Proposal to Undertake Tax-Administration for a District Official." Enchoria 12: 43-9.

Spalinger, A. 2017. "The Cycle of 309 Egyptian Months." In The Cultural Manifestations of Religious Experience: Studies in Honour of Boyo G. Ockinga, edited by C. Di Biase-Dyson, L. Donovan, and H. Behlmer, 377-81. ÄAT 85. Münster: Ugarit.

Spiegelberg, W. 1902. Demotische Papyrus aus den Königlichen Museen zu Berlin. Leipzig: Giesecke \& Devrient. 
Stadler, M. A. 2018. "Eine demotische Version des Töpferorakels? Der Papyrus Berlin P

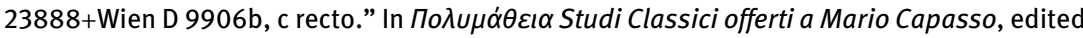
by P. Davoli, and N. Pellé, 395-411. Lecce: Pensa Multimedia.

Steele, J. M. 2000. "Eclipse Prediction in Mesopotamia." AES 54: 421-54.

Steele, J. M. 2015. "A Late Babylonian Compendium of Calendrical and Stellar Astrology." JCS 67: 187-215.

Stockhusen, M. 2012a. "Babylonische Astralwissenschaften im römerzeitlichen Ägypten: Das Beispiel Medînet Mâdi.” WdO 42: 85-109.

Stockhusen, M. 2012b. "Die Deutung kosmischer Erscheinungen am Beispiel von Sonnen- und Mondeklipsen: Ein Vergleich zwischen den Kulturräumen Mesopotamien und Ägypten im 1. Jt. v.Chr." In Disaster and Relief Management, edited by A. Berlejung, 445-70. FAT 81. Tübingen: Mohr Siebeck.

Symons, S. L. 2020. "Sun and Stars: Astronomical Timekeeping in Ancient Egypt." In Down to the Hour: Short Time in the Ancient Mediterranean and Near East, edited by K. J. Miller, and S. L. Symons, 14-51. TAC 8. Leiden: Brill.

Thijs, A. 2010. "The Lunar Eclipse of Takelot II and the Chronology of the Libyan Period.” ZÄS 137: $171-91$.

Török, L. 2009. Between Two Worlds: The Frontier Region between Ancient Nubia and Egypt 3700 $B C-A D$ 500. PdÄ 20. Leiden: Brill.

Trauneker, C. 1993. “Les résidents des rives du Lac Sacré: le cas d’Ankhefenkhonsou.” CRIPEL 15: 83-93.

van der Horst, P. W. 1987. Chaeremon. Egyptian Priest and Stoic Philosopher. The Fragments Collected and Translated with Explanatory Notes. EPRO 101. Leiden: Brill.

Vernus, P. 1981. “Omina calendériques et comptabilité d'offrandes sur une tablette hiératique de la XVIIle dynastie.” RdÉ 33: 89-124.

Vittmann, G. 1998. Der demotische Papyrus Rylands 9. ÄAT 38. Wiesbaden: Harrassowitz.

von Bomhard, A.-S. 2008. The Naos of the Decades: from the Observation of the Sky to Mythology and Astrology. OCMA Mon. 3. Oxford: OCMA.

von Känel, F. 1984. Les prêtres-ouâb de Sekhmet et les conjurateurs de Serket. BEHE SSR 87. Paris: Presses Universitaires de France.

von Lieven, A. 1999. "Divination in Ägypten." AoF 26: 77-126.

von Lieven, A. 2000a. "Der dritte Reiche der Dekane oder Tradition und Innovation in der Spätägyptischen Religion.” ARG 2: 21-36.

von Lieven, A. 2000b. Der Himmel über Esna. Eine Fallstudie zur Religiösen Astronomie in Ägypten am Beispiel der kosmologischen Decken- und Architravinschriften im Tempel von Esna. ÄA 64. Wiesbaden: Harrassowitz.

von Lieven, A. 2007. Grundriss des Laufes der Sterne. Das sogenannte Nutbuch. The Carlsberg Papyri 8. CNIP 31. Copenhagen: Museum Tusculanum.

von Lieven, A. 2016. "The Movement of Time: News from the 'Clockmaker' Amenemhet." In Rich and Great. Studies in Honour of AnthonyJ. Spalinger on the Occasion of his 70th Feast of Thot, edited by R. Landgráfová, and J. Mynářová, 207-31. Prague: Charles University in Prague, Faculty of Arts.

von Lieven, A. 2020. "Hellenistic Astronomy and the Priests." In Hellenistic Astronomy: The Science in Its Contexts, edited by A. C. Bowen, and F. Rochberg, 411-25. Leiden: Brill. von Lieven, A., and A. Schomberg. 2020. "The Ancient Egyptian Water Clock between Religious Significance and Scientific Functionality." In Down to the Hour: Short Time in the Ancient 
Mediterranean and Near East, edited by K. J. Miller and S. L. Symons, 52-89. TAC 8. Leiden: Brill.

Vycichl, W. 1984. Dictionnaire étymologique de la langue copte. Leuven: Peeters.

Wagner, M. 2018. "Die $h$ - $b=s$-Sterne, ein Versuch einer Einordnung." GM 254: 117-25.

Wegner, W. 2011. "Ein bislang unbekannter Beleg für eine Personalunion der Prophetenstellen der Tempel von Tebtynis und Akoris." SEP 8: 113-8.

Wespi, F. 2016. "Das Gesetz der Tempel: Ein Vorbericht zu den Priesternormen des demotischen Papyrus Florenz PSI inv. D 102.” In 10. Ägyptologische Tempeltagung: Ägyptische Tempel zwischen Normierung und Individualität - München, 29-31. August 2014, edited by M. Ullmann, 179-94. KSG 3.5: Akten der ägyptologischen Tempeltagungen. Wiesbaden: Harrassowtiz.

Wild, H. 1970. "Quatre statuettes du Moyen Empire dans une collection privée de Suisse." BIFAO 69: 89-130.

Wildung, D. 1977. Imhotep und Amenhotep: Gottwerdung im alten Ägypten. MÄS 36. Munich: Deutscher Kunstverlag.

Willems, H. 2007. Dayr al-Barshā, I: The Rock Tombs of Djehutinakht (No. 17K74/1), Khnumnakht (No. 17K74/2), and Iha (No. 17K74/3). With an Essay on the History and Nature of Nomarchal Rule in the Early Middle Kingdom. OLA 155. Leuven: Peeters.

Wilson, P. 1997. A Ptolemaic Lexicon: A lexicographical Study of the Texts in the Temple of Edfou. OLA 70. Leuven: Peeters.

Winkler, A. 2009. "On the Astrological Papyri from the Tebtunis Temple Library." In Actes du IXe Congrès International des Études Démotiques: Paris, 31 août - 3 septembre 2005, edited by Gh. Widmer, and D. Devauchelle, 361-75. BdÉ 147. Cairo: IFAO.

Winkler, A. 2016. "Some Astrologers and their Handbooks in Demotic Egyptian." In The Circulation of Astronomical Knowledge in the Ancient World, edited by J. M. Steele, 245-86. TAC 6. Leiden: Brill.

Winkler, A. 2018. "A Starry Summer Night in AD 142: A Theban Horoscope (Griffith MSS. 3.59) in Context." In Hieratic, Demotic, and Greek Studies and Text Editions. Of Making Many Books There is No End: In Honour of Sven P. Vleeming, edited by F. A. J. Hoogendijk, C. J. Martin, and K. Donker van Heel, 298-308. PLBat 34. Leiden: Brill.

Zauzich, K.-Th. 1974. “Drei neue Fragmente zu Pap. Carlsberg 9.” Enchoria 4: 157-58.

Zauzich, K.-Th. 2000. "P.Carlsberg 21 und 22: Zwei Briefe von Bücherfreunden.” In A Miscellany of Demotic Texts and Studies, edited by P. J. Frandsen, and K. Ryholt, 53-7. The Carlsberg Papyri 3. CNIP 22. Copenhagen: Museum Tusculanum.

Zivie-Coche, Ch. 2004. Tanis: travaux récents sur le tell Sân el-Hagar 3: Statues et autobiographies de dignitaires: Tanis à l'époque ptolémaïque. Mission française des fouilles de Tanis. Paris: Cybèle. 